I N T ER N ATIONAL MONETARY FUND

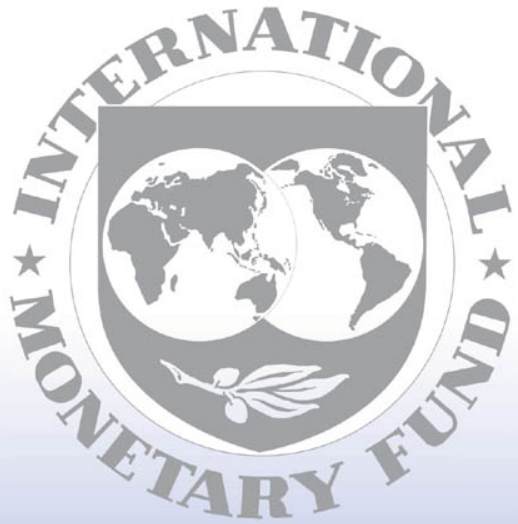

Staff

Country

Reports 


\title{
People's Republic of China-Hong Kong Special Administrative Region: 2009 Article IV Consultation-Staff Report; Staff Statement; and Public Information Notice on the Executive Board Discussion
}

The following documents have been released and are included in this package:

- $\quad$ The staff report prepared by a staff team of the IMF, following discussions that ended on October 22, 2009, with the officials of People's Republic of China-Hong Kong Special Administrative Region on economic developments and policies. Based on information available at the time of these discussions, the staff report was completed on November 3, 2009. The views expressed in the staff report are those of the staff team and do not necessarily reflect the views of the Executive Board of the IMF.

- A staff statement

- $\quad$ A Public Information Notice (PIN)

The policy of publication of staff reports and other documents allows for the deletion of market-sensitive information.

\author{
Copies of this report are available to the public from \\ International Monetary Fund • Publication Services \\ $70019^{\text {th }}$ Street, N.W. • Washington, D.C. 20431 \\ Telephone: (202) 623-7430 • Telefax: (202) 623-7201 \\ E-mail: publications@imf.org Internet: http://www.imf.org
}

\section{International Monetary Fund \\ Washington, D.C.}


This page intentionally left blank 


\title{
INTERNATIONAL MONETARY FUND
}

\section{PEOPLE'S REPUBLIC OF CHINA-HONG KONG SPECIAL ADMINISTRATIVE REGION}

\section{Staff Report for the 2009 Article IV Consultation Discussions}

\begin{abstract}
Prepared by the Staff Representatives for the 2009 Article IV Consultation with the
\end{abstract} People's Republic of China—Hong Kong Special Administrative Region

Approved by Mahmood Pradhan and Tamim Bayoumi

November 3, 2009

Mission. A staff team visited Hong Kong SAR, October 12-22, 2009 consisting of N. Chalk (Head), P. N'Diaye (APD), E. Takats (MCM), and V. Arora (Senior Resident Representative). Messrs. He and Yung (OED) participated in the discussions.

Focus. The 2009 consultation centered on the policies needed in the coming months to manage the economic recovery and the opportunities for Hong Kong SAR should the Mainland successfully rebalance from investment and exports toward private consumption.

\section{Executive Summary}

- Hong Kong's economy was severely affected by the global financial crisis (through both trade and financial channels). A recovery is now underway, fueled by growth on the Mainland, supportive policies, and accommodative monetary conditions imported from the U.S.

- With substantial liquidity in the system, there is a prospective risk that a credit-asset price cycle could take hold, ultimately leading to macroeconomic volatility.

- The authorities are fully aware of that possibility, having experienced such cycles before, and have a comprehensive and graduated contingency plan in place to deploy, as needed, a combination of regulatory measures and, potentially, increasing the supply of available land.

- At the same time as there are risks of asset price inflation, the economic recovery remains fragile and exposed to the risk of a weakening of external demand. As such, the authorities indicated they would act cautiously in deciding the pace of withdrawal of fiscal stimulus in the 2010 Budget.

- Over a longer horizon, the government has laid out a broad strategy to support the key industries that currently drive the Hong Kong economy, and diversify into other areas through the facilitation of private investment in healthcare, education, research and development, testing and certification, and creative and environmental industries.

Exchange arrangement. Currency board with a trading band of HK\$7.75-7.85 per U.S. dollar. 


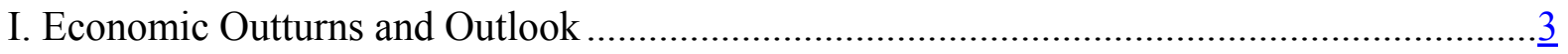

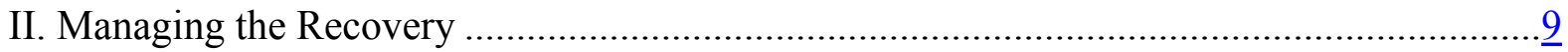

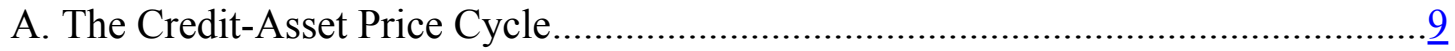

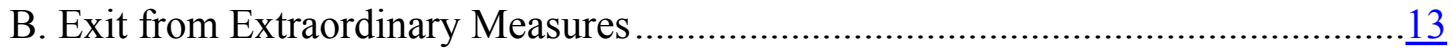

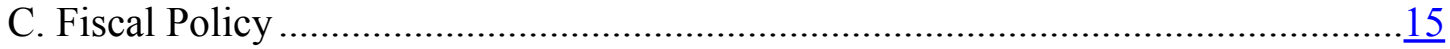

III. The Implications of Mainland Rebalancing.........................................................

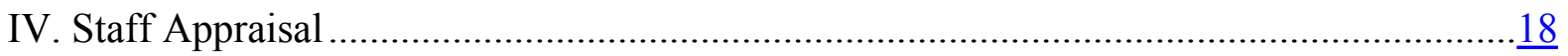

Boxes

1. Exchange Rate Assessment........................................................................................... 7

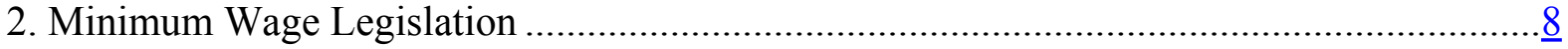

3. Macroeconomic Implications for Hong Kong SAR of U.S. Credit Easing ........................11

4. Proposed Changes to the Deposit Protection Scheme .................................................14

5. Recent Steps Toward Greater Financial Integration with the Mainland ...........................17

Figures

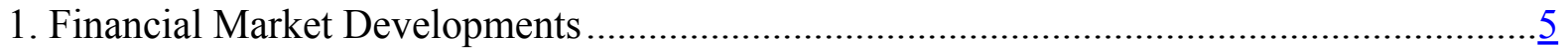

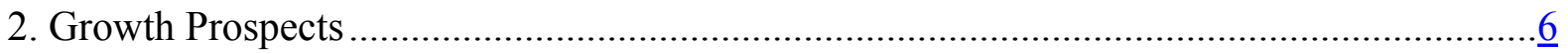

3. Spillovers from U.S. Credit Easing …..............................................................

Tables

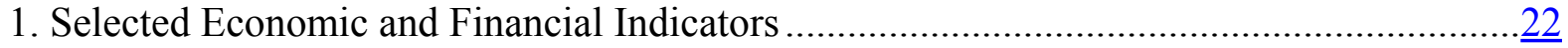

2. Consolidated Government Accounts .......................................................................... $\underline{23}$

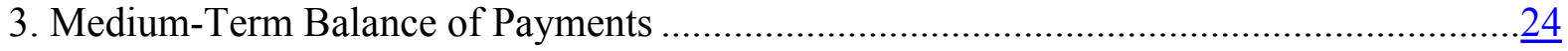

4. Medium-Term Macroeconomic Framework.................................................................25

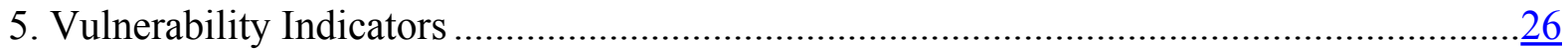




\section{ECONOMIC OUTTURNS AND OUTLOOK}

1. Asset markets. The pressures experienced by Hong Kong SAR following the failure of Lehman Brothers abated in the latter part of 2008, a result of the concerted policy efforts of the authorities and improving conditions in global capital markets. Following a decline in the fourth quarter, property markets have experienced a turnaround, which has been particularly marked in the luxury residential market. Equity prices have risen by 70 percent since mid-March (Figure 1). In September, the Hong Kong government sold sovereign bonds in the local market aiming to promote development of local currency bond markets. The issue was very positively received by investors.

2. Activity. Hong Kong SAR suffered a sharp downturn in late 2008 and growth in the first quarter of 2009 was the worst on record. In contrast, the second quarter outturn was surprisingly strong and well above consensus. Consumption of financial services were particularly buoyant. In recent data, retail sales and financial services have continued to strengthen, offset in part by somewhat weaker trade and trade-related services (Figure 2). Staff now project the contraction will be contained to around 2 percent this year with a return to growth of around 5 percent in 2010.

3. Labor markets. Job losses have been relatively modest, especially given the steepness of the downturn. Unemployment has risen less steeply than in previous recessions and, in seasonally adjusted terms, now stands at 5.3 percent. In addition, real payrolls have fallen only slightly (by around $1 / 2$ percent in the 12 months to June). The unemployment rate now appears close to its cyclical peak and should decline in the coming months, supported by fiscal measures and the economic recovery.

4. Inflation. Headline inflation has declined as a result of lower food inflation and the direct effects of fiscal measures (such as the concessions in rates and public housing rent). Consumer price increases will remain muted through the course of next year although housing costs will likely pick-up.

5. External. The current account surplus

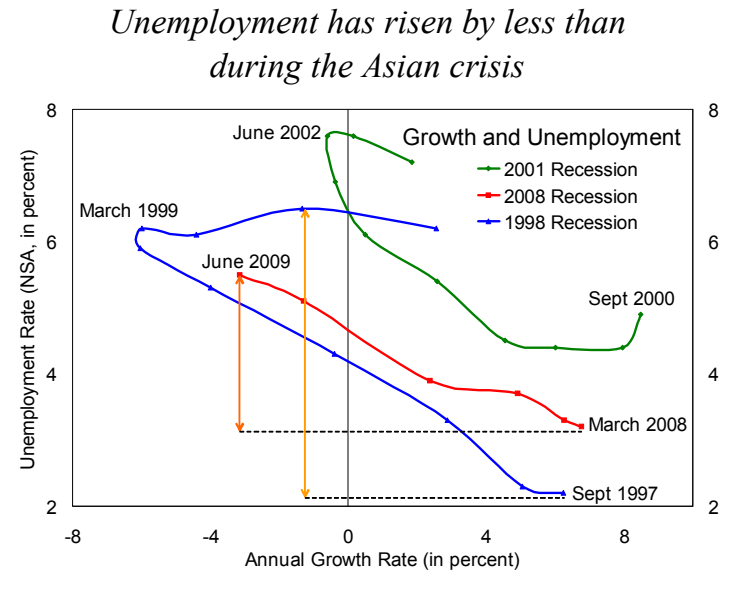

Inflation is falling rapidly

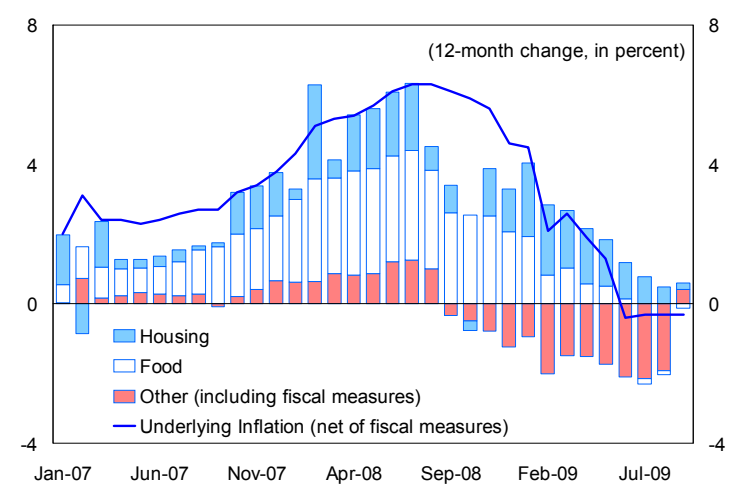
narrowed modestly to around 11/1/2 percent of GDP in the first half of 2009, down from $14 \frac{1}{4}$ percent in 2008 , mainly owing to weak services exports and income flows. 
Nevertheless, official reserves rose to US\$223 billion by end-August as the Hong Kong Monetary Authority (HKMA) absorbed significant capital inflows in accordance with the design of the Linked Exchange Rate System.

6. Fiscal policy. In February, the government announced an expansionary budget underpinned by a series of tax reductions and higher capital spending. In May, the government supplemented this with a further HK $\$ 16.8$ billion (1 percent of GDP) fiscal package. The government also put in place a program of partial loan guarantees to help alleviate the tightening of credit conditions experienced by small and medium sized companies, particularly in late 2008 . The authorities estimate that the discretionary policy measures taken since 2008-09, amounting to over 5 percent of GDP, will add around 2 percent to growth this year and the loan guarantee scheme would secure more than 240,000 jobs.

7. Banking system. Hong Kong banks have withstood the downturn well, reflecting effective regulation and supervision and a cautious approach to lending by Hong Kong banks. The banks were generally not exposed to the securitized products at the center of the crisis in the U.S., have strong internal risk management systems, are highly liquid, and have low loan-to-deposit ratios. While risk spreads on Hong Kong banks rose in late 2008 this was largely a product of increased global risk aversion. Capital adequacy ratios were $161 / 2$ percent at end-June, up from 13.8 percent in September 2008, with around $3 / 4$ in the form of Tier 1 capital. This higher capital ratio reflects a contraction in lending, a shift in portfolio allocations toward lower risk assets, profit reinvestment, and some raising of new capital. In terms of leverage, Tier 1 capital makes up over 5 percent of assets (adjusted for goodwill, intangible and deferred tax assets). Banking system profitability has declined due to higher provisioning and tighter interest margins. In addition, the economic slowdown has worsened credit quality, particularly on lending to small and medium sized enterprises. Nevertheless, nonperforming loans remain at low levels (classified loans were $1 \frac{1}{2}$ percent of the total in June) and stress tests show the banking system to be robust even in a very negative scenario.

8. Exchange rate assessment. The real exchange rate has appreciated by 5 percent over the past year. However, the current level of the real exchange rate does not appear out of line with economic fundamentals. Staff's estimated range for the equilibrium level of the real exchange rate has widened but remains anchored around its current level. However, the overvaluation suggested by the macroeconomic balance approach may be less reliable and overly influenced by the large shift in net foreign asset position in late 2008 (Box 1). Looking forward, and given the volatile global environment, there was agreement that maintaining a high degree of flexibility in the economy would be essential. In this regard, staff argued that the level of the statutory minimum wage (which is expected to be introduced next year) should be set conservatively at a level that will protect lower income workers but with minimal distortion to Hong Kong SAR's labor markets (Box 2). 
Figure 1. Financial Market Developments

Main Message: Capital inflows have kept the Hong Kong dollar at the strong side of the band and nominal interest rates have remained close to the zero bound. Equity markets have rallied.

Since last year's global market volatility, the currency has been on the strong side of the convertibility undertaking...

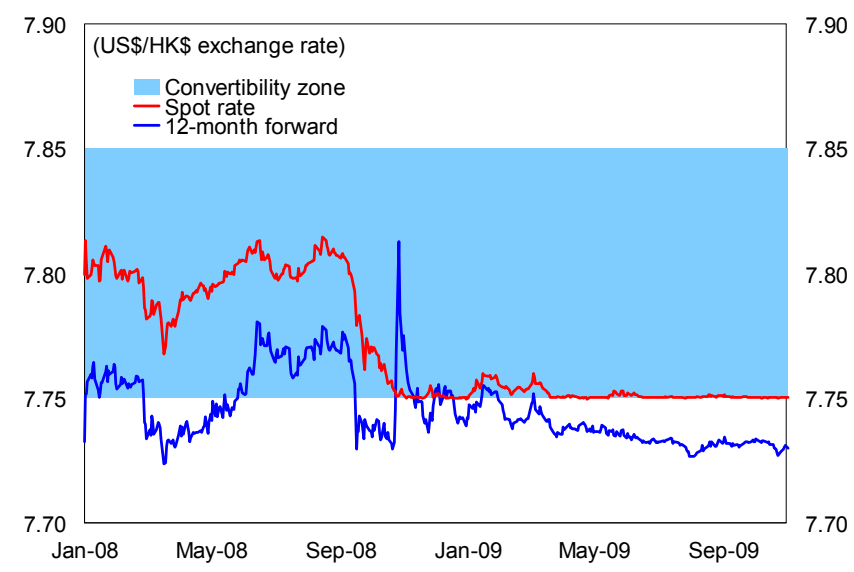

Ample domestic liquidity and a preference for high quality instruments have pushed interest rates to zero...

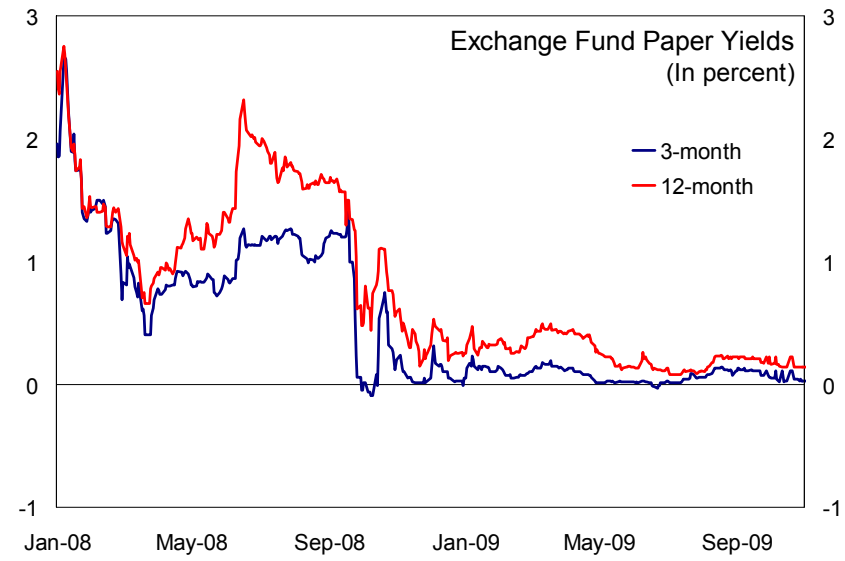

Spreads on Hong Kong banks have declined steadily.

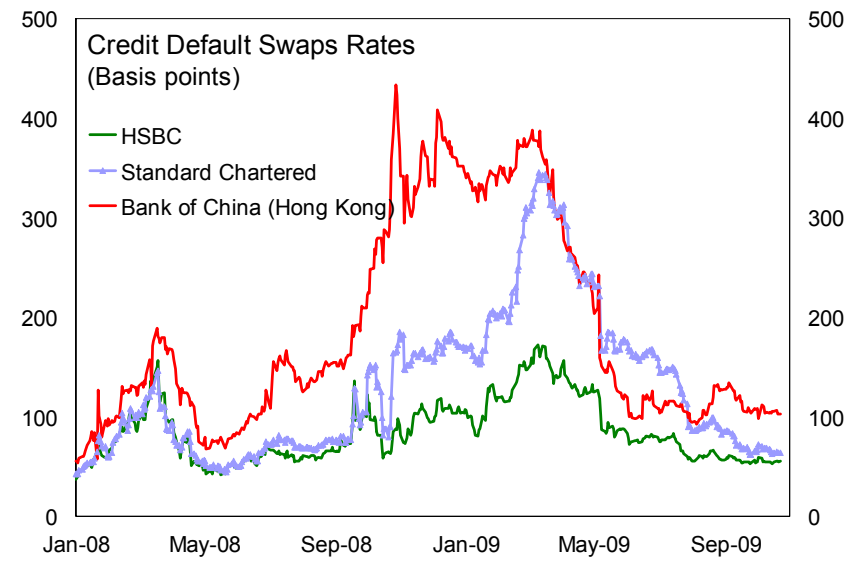

Sources: Bloomberg; CEIC Data Company Ltd.; and staff estimates. ...and, under the rules-based exchange rate mechanism, the HKMA has intervened on repeated occasions.

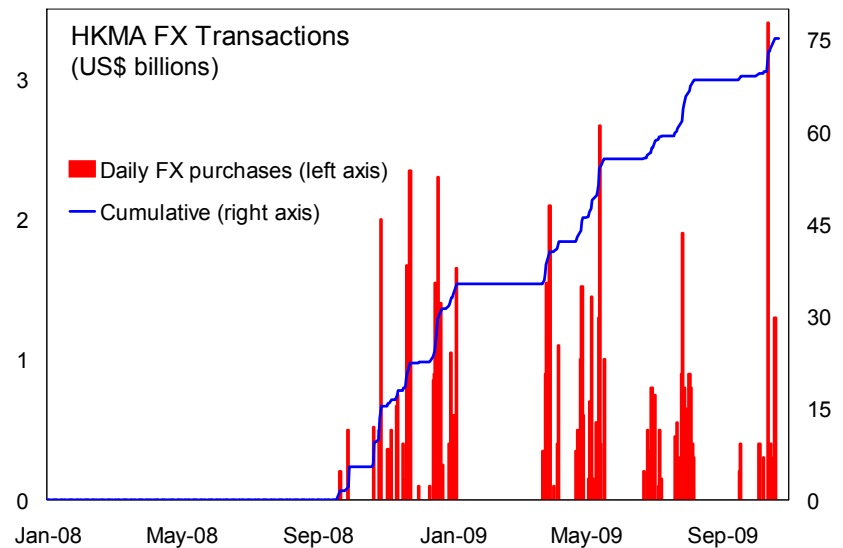

... and interbank rates have fallen along the yield curve.

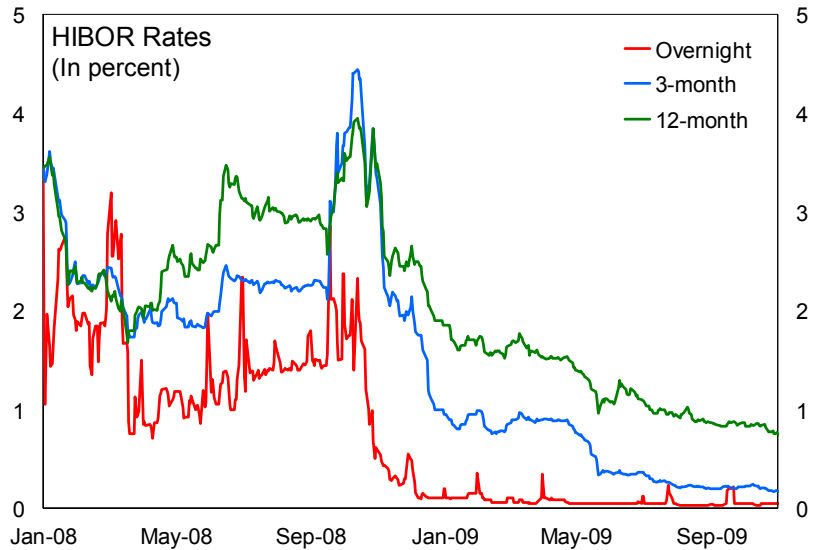

Improving investor sentiment, particularly toward the Mainland, has led to an upswing in equity prices.

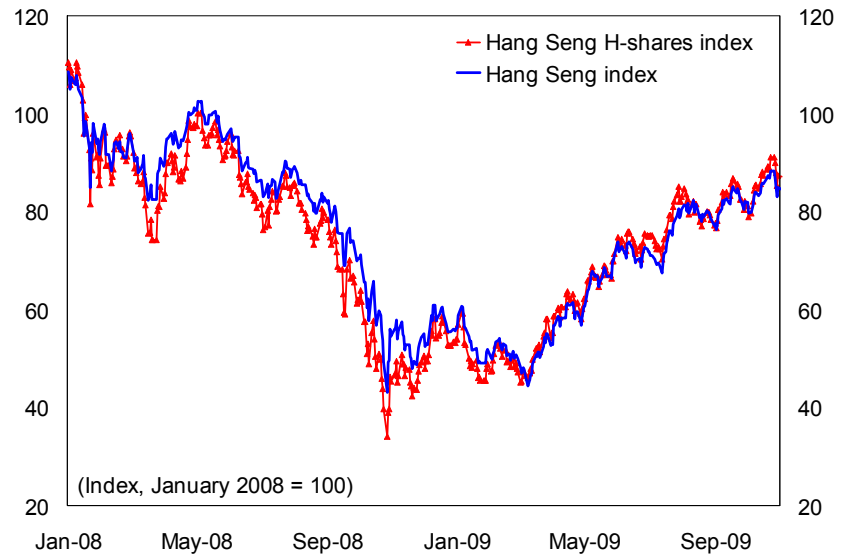


Figure 2. Growth Prospects

Main Message: The economic downdraft from the global crisis has been forceful. However, there are emerging signs of recovery.

Positive growth resumed in the second quarter with particular improvements in consumption.

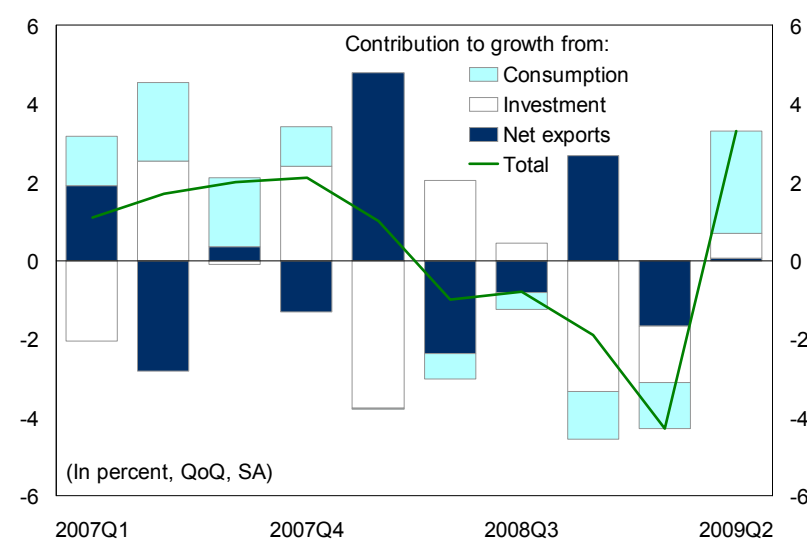

...helping retail sales to rise above pre-crisis levels.

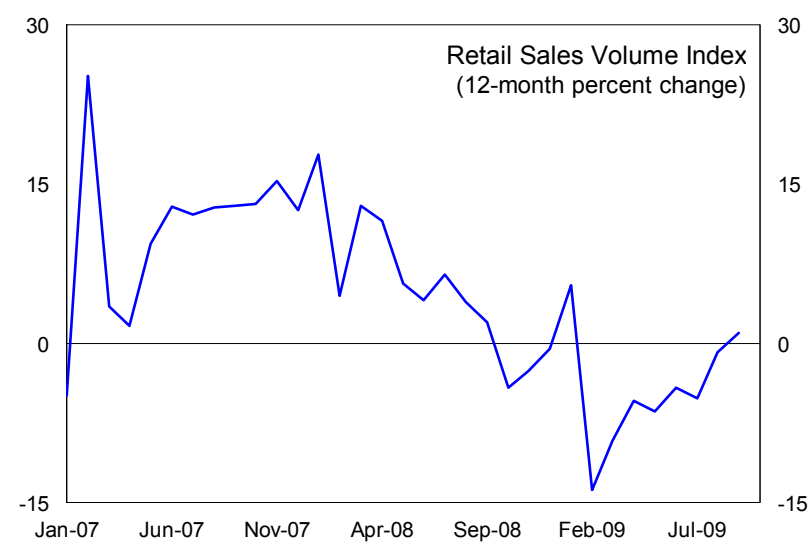

Financial market activity has picked up, adding to growth through increased consumption of financial services.

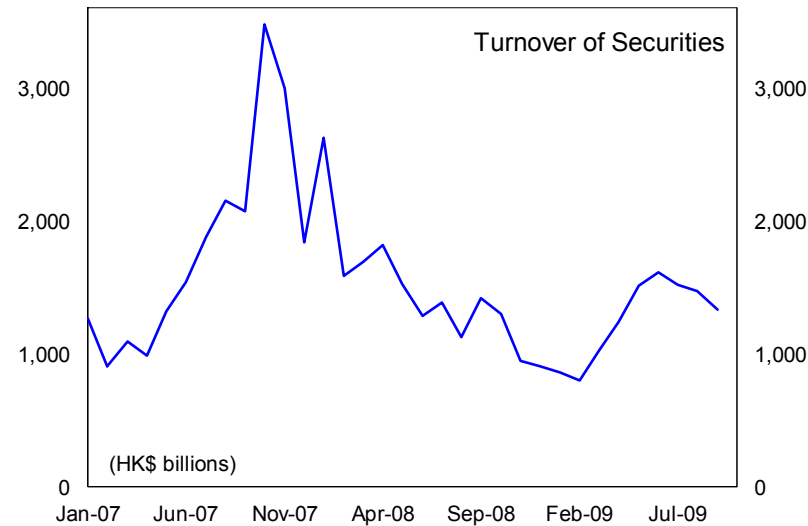

Sources: CEIC Data Company Ltd.; and staff estimates.
The number of tourists, particularly from the Mainland has declined, but recent data show some turnaround...

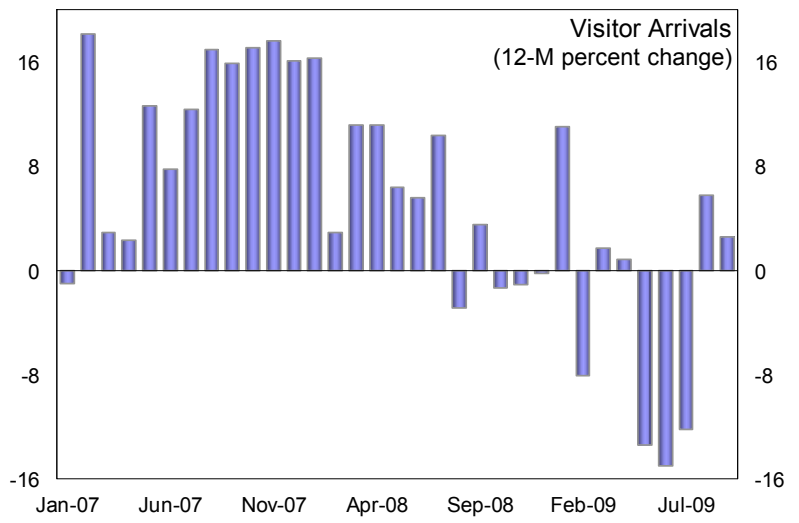

Consumer and business confidence have improved but are still relatively pessimistic.

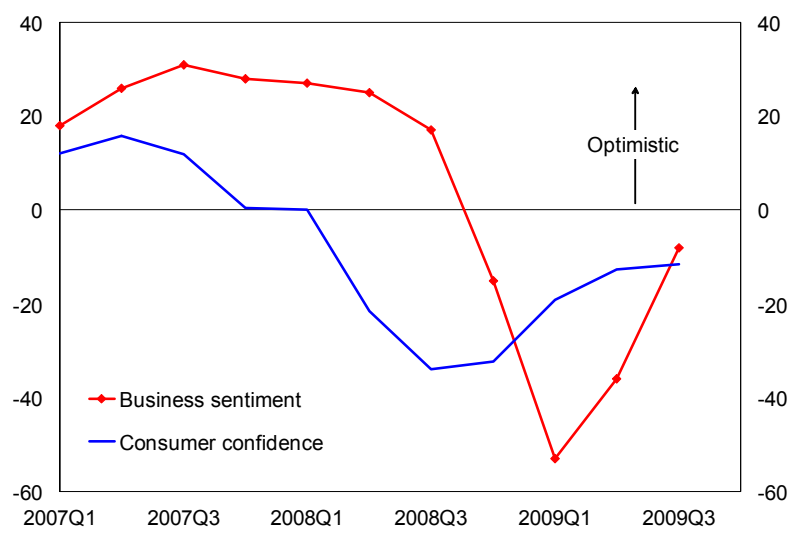

The contraction in trade has abated but exports remain weak.

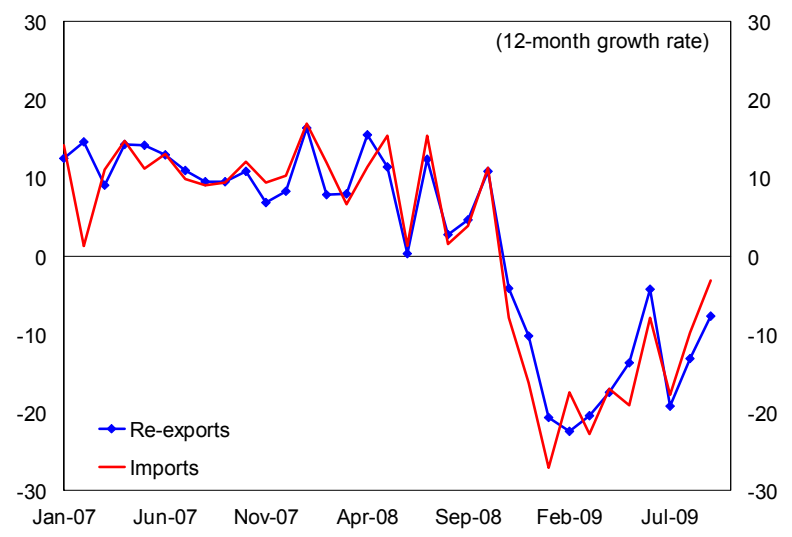




\section{Box 1: Exchange Rate Assessment ${ }^{1}$}

The current value of the Hong Kong dollar appears to be broadly in line with the level suggested by medium-term fundamentals.

Three alternative empirical approaches were employed based on a cross-section of international financial centers which, like Hong Kong SAR, have high saving rates, low dependency ratios, and relatively low levels of investment. The global financial crisis and its impact on the determinants of the equilibrium real exchange rate-particularly on global asset returns and growth prospects-have

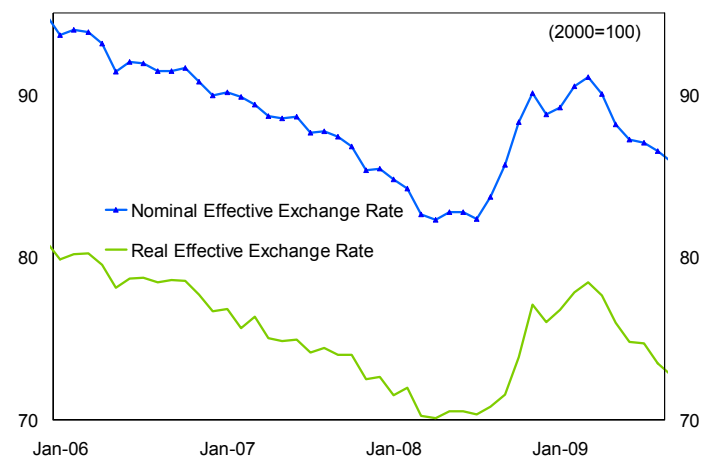
meant that there is a significantly larger degree of uncertainty than usual in assessing the equilibrium level of the real exchange rate.

\section{The macroeconomic balance approach} indicates that the real exchange rate is 20 percent above its medium-term value. This is due to the 50 percent of GDP increase in the net foreign asset (NFA) position at end-2008, predominantly resulting from valuation changes. Although this higher NFA is expected to be, in part, transitory it nevertheless raises the estimated equilibrium current account. This, in turn, implies the

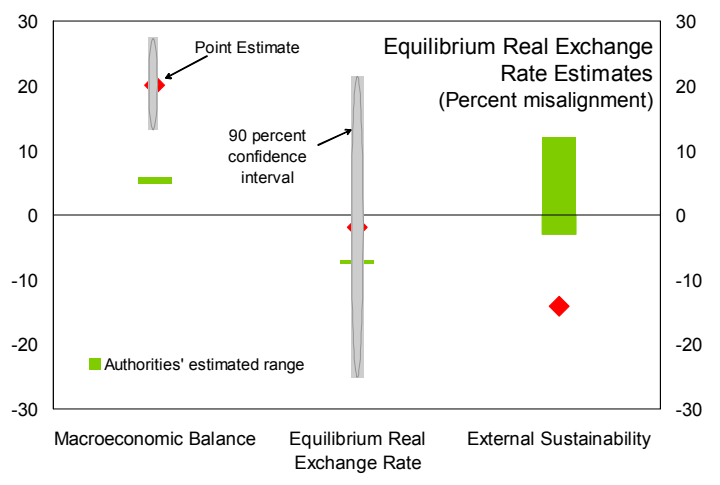
exchange rate would need to depreciate in order to bring the actual current account into line with its norm.

The equilibrium real exchange rate approach suggests that the real exchange rate is currently undervalued by 2 percent, a smaller amount than a year ago mostly due to the real appreciation over the past 12 months.

The external sustainability approach shows the real exchange rate to be 14 percent undervalued. This reflects the significant rise in NFA, as well as higher net foreign income inflows, which reduces the level of the trade balance that is needed to stabilize NFA.

\footnotetext{
${ }^{1}$ Staff assessments are based upon panel regressions estimated by generalized method of moments covering six international financial centers (Belgium, Hong Kong SAR, Luxembourg, Netherlands, Singapore, and Switzerland). The authorities' assessments use a similar approach but with slightly different model specifications.
} 


\section{Box 2: Minimum Wage Legislation}

In October 2006 the government put in place a voluntary scheme (the Wage Protection Movement) to ensure that wages paid to cleaning workers and security guards were above a certain minimum. The policy proved to be ineffective. This led the government to submit a Bill to the Legislative Council in July 2009 for a statutory minimum wage, with the intention that the legislation would come into effect by early 2011.

The content of the Bill:

- Goals. To prevent excessively low wages without jeopardizing Hong Kong SAR's labor market flexibility, economic freedom and competitiveness, or reducing employment opportunities for vulnerable workers.

- Institutions. A provisional minimum wage commission-with members from academia, labor, business, and the government that are appointed by the chief executive - was established in February 2009 to advise the government on the appropriate level of the initial minimum wage. Under the current bill, the commission would become a permanent statutory body that would make recommendations to the chief executive in council, including on the level of the minimum wage and the timing and frequency of reviews.

- $\quad$ Coverage. The minimum wage would apply to all employees in Hong Kong SAR, except for specified student interns and live-in domestic workers. A special regime would apply for persons with disabilities.

- $\quad$ Determining the minimum wage. The level of the minimum wage-determined as a minimum hourly wage rate-would be established by the bill. The chief executive in council will determine the minimum wage rate upon advice from the minimum wage commission. The level of the minimum wage, how often the level will be revisited, and whether that level will be indexed or fixed in nominal terms are issues that remain to be determined.

- $\quad$ Enforcement. The labor department will be responsible for enforcement. Breaches of the legislation will be subject to a maximum fine of $\mathrm{HK} \$ 350,000$ and three years imprisonment.

- Data. The census and statistics department, in conjunction with other government departments, is undertaking supplementary surveys to build a disaggregated database on the demographics of both enterprises and workers in low paying sectors. That information will be made available to the minimum wage commission to support them in arriving at an "evidence-based" recommendation on the initial level of the minimum wage. 


\section{MANaging THe Recovery}

\section{A. The Credit-Asset Price Cycle}

9. The nature of inflows. Hong Kong SAR faces a somewhat unique situation. Abundant U.S. dollar liquidity and an expansionary credit policy in the Mainland have created significant capital inflows. In contrast, other economies with a pegged exchange rate have generally witnessed a contraction in monetary aggregates as capital has flowed out. In the early stages of the crisis, the flows into Hong Kong SAR reflected an unwinding of carry trades and a repatriation of funds by corporations to meet their local funding needs. More recently, a larger share of such flows have been related to a broader global asset allocation into Asia, as well as nonresident interest in Hong Kong initial public offerings.

Hong Kong SAR is unique in the scale of the monetary expansion it has imported.

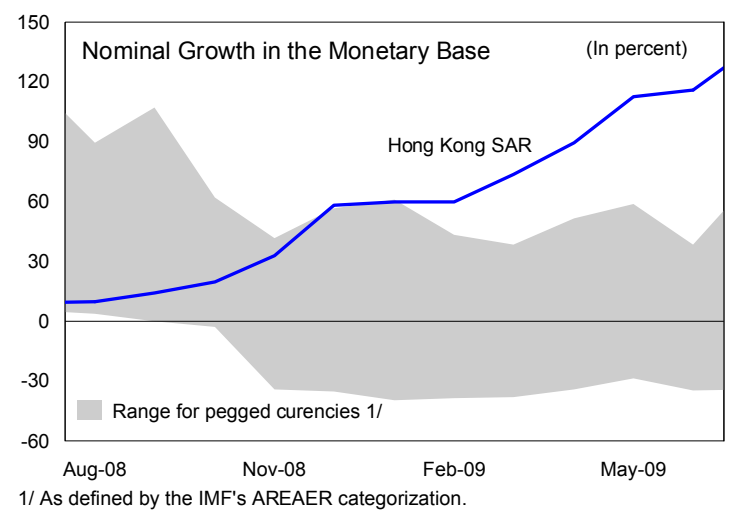

10. Implications. Most evidently, these inflows have led the exchange rate to hit the strong side of the convertibility band on numerous occasions and the HKMA has intervened to purchase foreign currency. The resulting expansion in Hong Kong dollar liquidity has driven interest rates to near-zero. The 130 percent growth in the monetary base (through September) has, however, translated into only a modest expansion of credit, as the alreadyconservative banks have shown lending restraint and the demand for credit has declined. This combination of factors has implied a sharp fall in the money multiplier (Figure 3).

11. Macro-financial linkages. These very accommodative monetary conditions have facilitated an economic recovery but also carry the potential to spur a future credit-asset price cycle. Given the high level of liquidity in the system, credit growth has the potential to pick up quickly. Higher credit could drive higher asset valuations which, in turn, could be used as collateral to support greater borrowing. Even with banks being highly conservative in their lending behavior one could still see volatility in output, consumption, employment, and inflation if such a financial accelerator process begins to play out. The size of the output gap and the openness of the economy would indicate that asset price inflation could move well ahead of consumer price inflation (Box 3). This could
U.S. interest rates are expected to remain low for an extended period

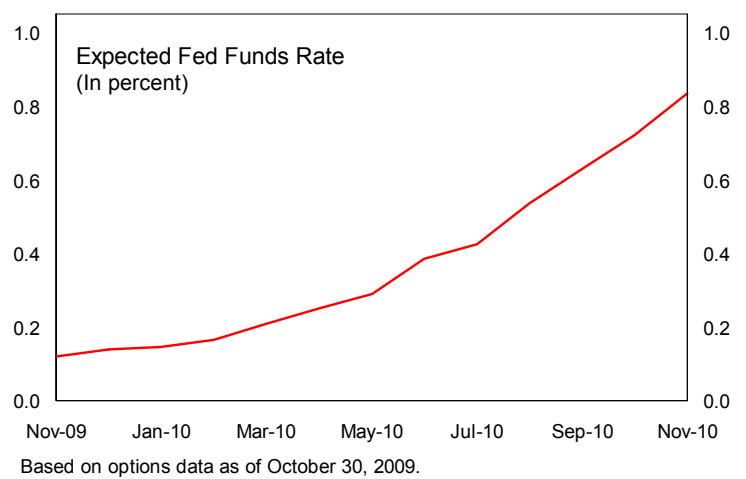


Figure 3. Spillovers from U.S. Credit Easing

Main Message: The nature of the Linked Exchange Rate System has meant that U.S. credit easing has been imported. This increase in liquidity has, so far, not led to a broader credit expansion.

The expansion in the Federal Reserve's balance sheet and decline in U.S. interest rates...

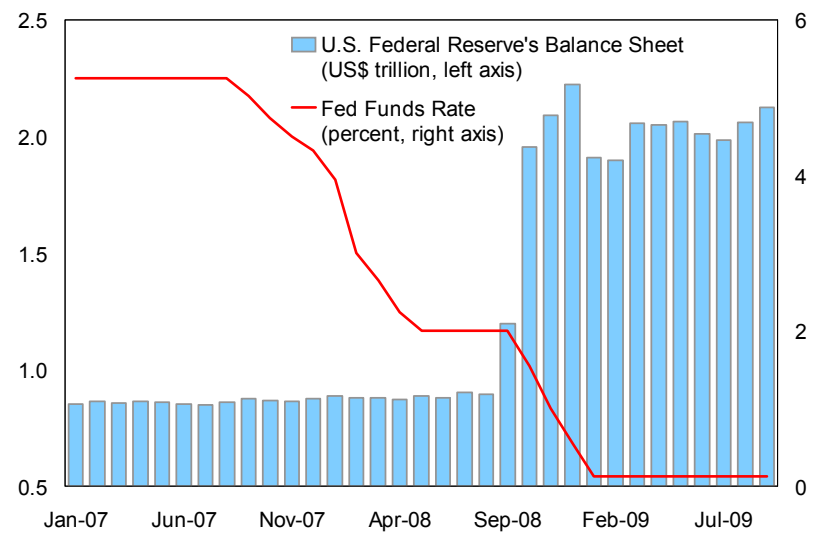

This has not translated into broader growth of monetary aggregates since the money multiplier has fallen.

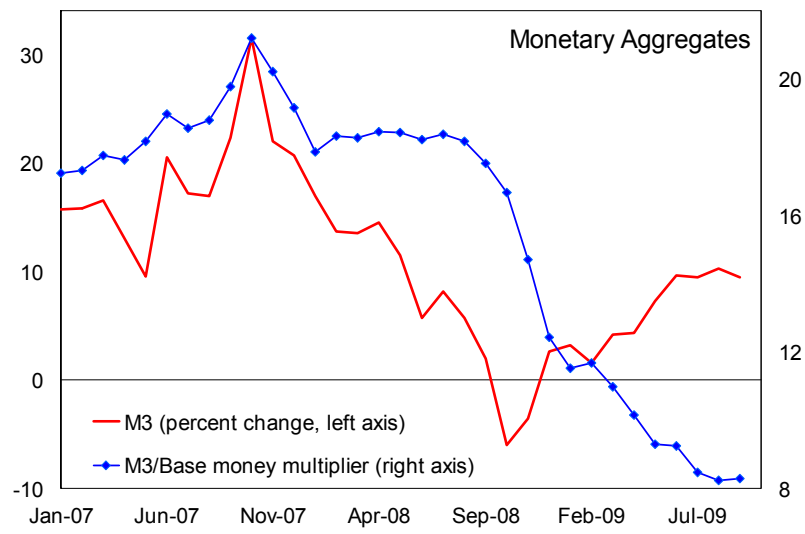

While overall credit growth has stagnated, mortgage lending has been picking up in recent months...

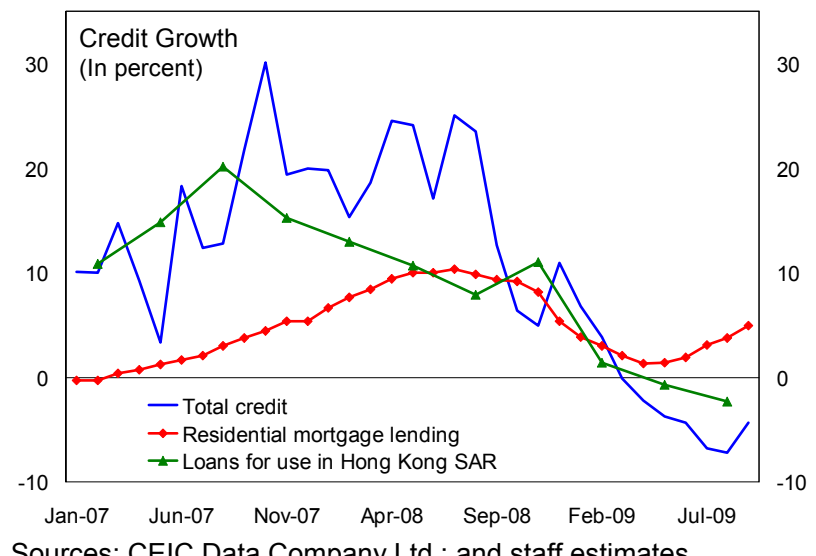

...has automatically fed through to an increase in Hong Kong dollar liquidity.

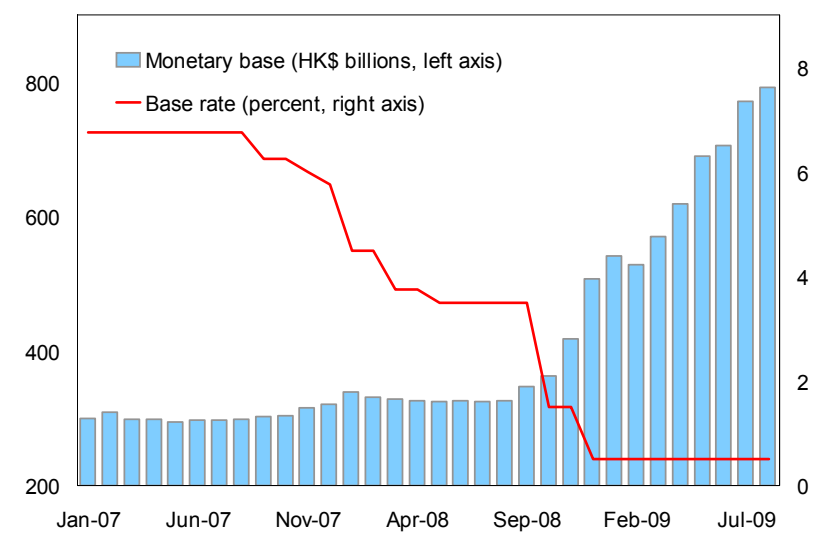

The issuance of short-term Exchange Fund Paper has moderated the expansion in the Aggregate Balance.

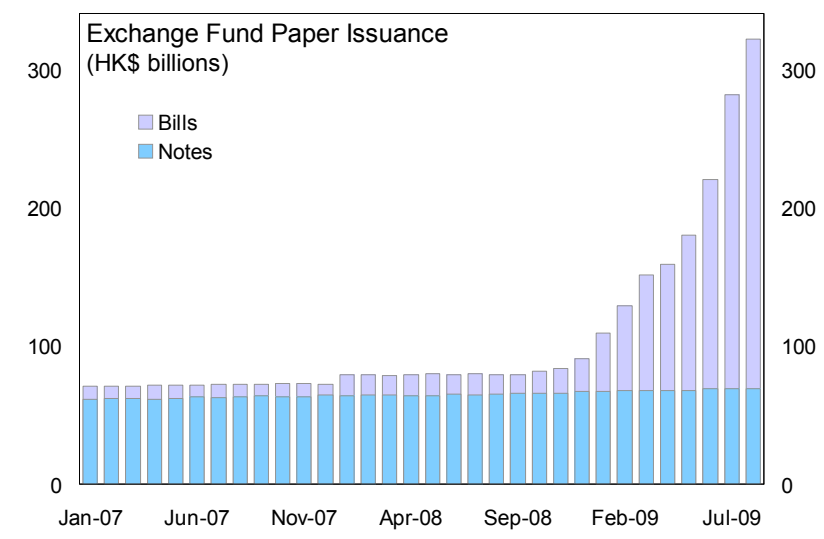
...and there has been a resurgence in both real estate prices and transaction volumes.

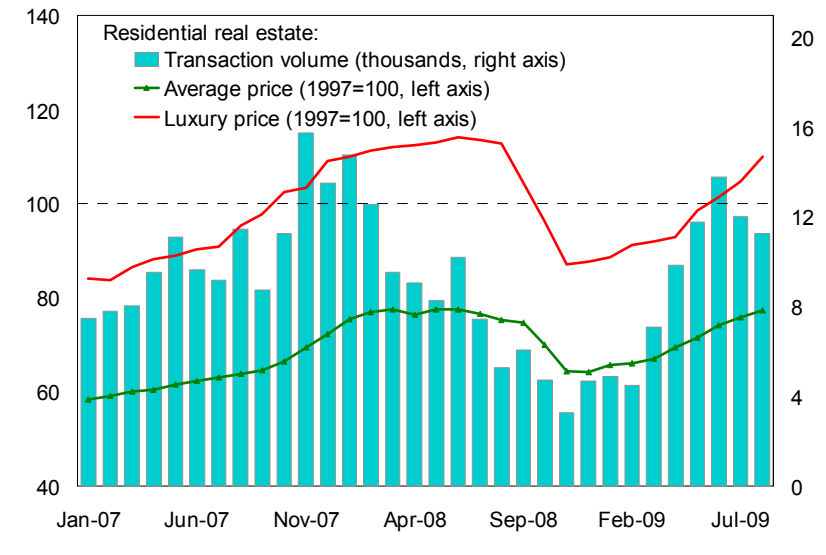




\section{Box 3: Implications for Hong Kong SAR of U.S. Credit Easing ${ }^{1}$}

A continuation of expansionary monetary policies in the U.S. together with a recovery in Mainland China has the potential to create pressures in Hong Kong asset markets, complicating macroeconomic management. The risks to consumer price inflation appear more muted.

Model simulations were carried out using a multi-country GIMF model to examine the potential impact on Hong Kong SAR of an early and strong recovery in the Mainland economy, combined with expansionary monetary conditions in the U.S. The simulations indicate that:

- A resumption of the credit channel in Hong Kong SAR, and a turnaround in the money multiplier, has the potential to create inflation in both goods and asset markets.

- Such expansionary financial conditions will have a greater impact on asset price inflation, manifested in the model through a strong increase in equity prices. These higher asset prices could, through a financial accelerator mechanism, increase credit growth and potentially fuel an asset price-credit cycle with adverse implications for output and employment volatility.

- Goods price inflation would also pick up, but to a much lesser extent since it will take time to unwind the excess capacity in goods markets.
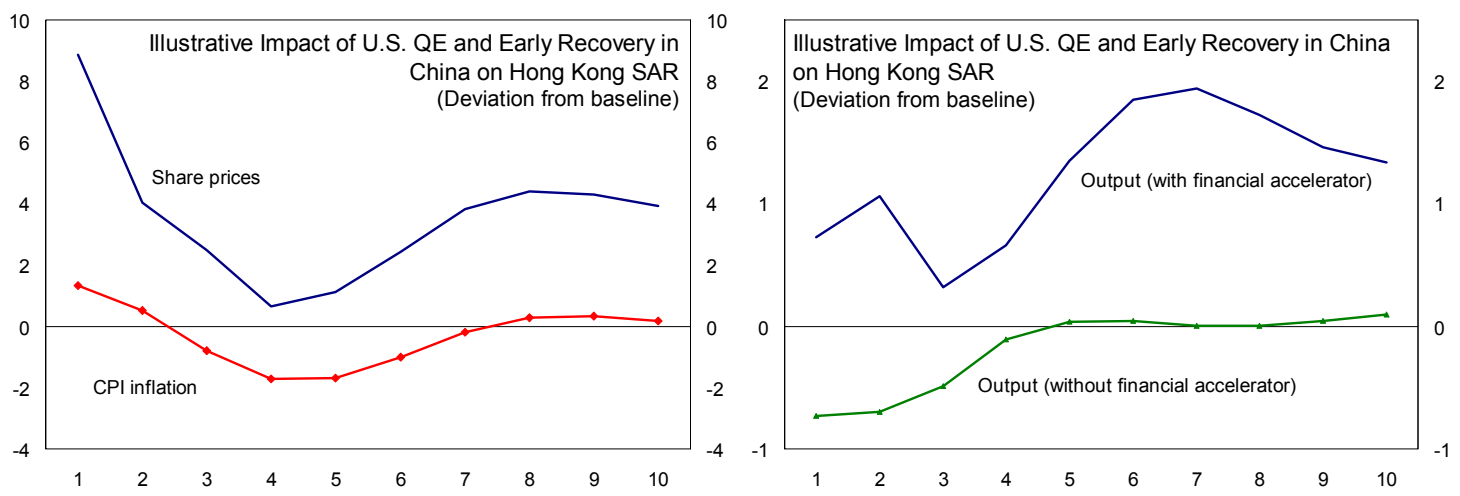

- $\quad$ Fiscal policy could be used to alleviate some of the asset price pressures. However, attempting to restrain asset price inflation through fiscal policy alone could entail large output losses and run the risk of derailing the economic recovery. Prudential measures, therefore, can be a useful complement to countercyclical fiscal policy to lessen macroeconomic volatility.

In addition to the GIMF approach, staff also employed a richer dynamic macroeconomic model that incorporates a contingent claims approach to capture movements in household, corporate, and bank balance sheets. Like the GIMF, the analysis suggests that countercyclical measures that limit borrowers' leverage and increase lenders' capital during the upturn can help contribute to better management of financial risks and lessen macroeconomic volatility. Such measures are, however, by no means a panacea.

\footnotetext{
${ }^{1}$ See N'Diaye, "Macroeconomic Implications for Hong Kong SAR of Accommodative U.S. Monetary Policy," IMF Working Paper (forthcoming); and N'Diaye, "Countercyclical Macro Prudential Policies in a Supporting Role to Monetary Policy," IMF Working Paper (forthcoming).
} 
occur even without strains showing up in the financial system. However, it is important to note that, as yet, price rises in both equities and the mass property market do not appear out of line with regional comparators.

\section{The policy response. The Hong Kong system} already has effective "circuit breakers" to manage risks associated with the credit cycle. These include a set of very prudent regulatory restraints, good risk management systems in the banks, and a relatively small wealth effect from asset price increases.

\begin{tabular}{lrr}
\multicolumn{3}{c}{$\begin{array}{r}\text { Recent Asset Price Changes } \\
\text { (YoY change, in percent) }\end{array}$} \\
\hline & Equity & $\begin{array}{r}\text { Propert } \\
\text { y }\end{array}$ \\
\hline & 34.7 & 1.9 \\
\hline Indonesia & 31.3 & -3.2 \\
Taiwan Province & & \\
of China & 21.1 & 4.2 \\
China & 20.2 & -3.7 \\
Thailand & 16.3 & 2.7 \\
Hong Kong SAR & 15.5 & -1.0 \\
Korea & 13.3 & -11.0 \\
Singapore & 2.3 & -1.4 \\
Australia & 2.3 & -3.1 \\
New Zealand & -10.0 & -10.0 \\
Japan &
\end{tabular}

Nevertheless, given the strength of the factors now at play - the scale of the monetary expansion in the United States, the size of the Mainland's policy stimulus, and the asynchronous cycles in the United States and China-staff argued for some form of countercyclical regulatory action to mitigate the asset price cycle. The options could include:

- Capital. Risk weights for particular assets could be increased as a mechanism to restrain bank lending including, for example, by differentiating risk weights based upon the loan-to-value ratio of individual mortgages. However, it is far from clear that such measures would have a material impact in Hong Kong SAR. In general, banks already far exceed regulatory capital so that even substantially higher requirements would, for the most part, be unlikely to bind.

- $\quad$ Provisioning. Some form of through-the-cycle provisioning could lower the profits associated with lending to certain asset classes and thus curb lending activities. However, in Hong Kong SAR, banks already maintain nondistributable regulatory reserves (amounting to 0.6 percent of total loans at end-June). In addition, the authorities pointed out that even during the property cycle that followed the Asia crisis — when average property prices fell almost 70 percent — default rates remained modest. Therefore, calibrating any form of expected loss provisioning based upon historical data would have only a modest impact on the size of needed provisioning.

- Loan-to-value ratios. Limits could be tightened but the existing maximum (of 70 percent), which has been maintained since 1991, is already very conservative compared to other jurisdictions. It is also widely accepted-by banks, regulators, and the general public - as an appropriately prudent level for Hong Kong SAR.

Nevertheless, the mission argued that it may be worth considering some tightening of loan-to-value ratios for certain types of loans (for example, for investment properties or for those luxury markets where prices have been going up rapidly).

- Underwriting. The most effective regulatory tool appears to be through the tightening of underwriting standards, not least because such changes are specific and can be 
carefully targeted. The authorities noted that they were already taking action to ensure banks' loan approval processes were sufficiently cautious and strictly conformed to existing regulatory requirements. The regulators had undertaken thematic examinations to gauge industry practices in equity margin financing and residential mortgage lending and would shortly be providing guidance to banks based upon their findings. In addition, the HKMA has issued a circular to banks to express concern that recent aggressive mortgage pricing practices may not prove sustainable over a longer horizon. Staff argued that further steps to strengthen standards- for example, by ensuring that banks appropriately differentiate between loans used to finance investment properties and by tightening eligibility criteria for mortgage insurance - could be considered. In addition, the authorities could explore lowering the existing maximum debt servicing ratio for mortgages (which is currently set at between 50 and 60 percent) based upon the nature and size of the underlying loan.

- $\quad$ Land sales. The chief executive's October 14 policy address indicated that the government would closely monitor market changes and, if necessary, fine-tune its land supply arrangements with a view to quickening the pace of bringing readily available residential sites to the market.

13. Broad strategy. The authorities agreed that some changes to prudential regulations were warranted in the interest of maintaining banking stability and indicated that they already had a contingent, pre-emptive and graduated strategy to handle signs of rapid rises in asset price movements. This involved a two-pronged approach involving "health warnings" to both borrowers and lenders, as well as steps to ensure that banks were sufficiently reflecting potential risks in their lending decisions. The authorities indicated they were particularly monitoring the extent to which price increases in the luxury property marketwhich makes up around 5 percent of total sales volumes - were spilling over into the mass market. In this regard, on October 23, the HKMA issued a circular lowering the maximum loan-to-value ratio (to 60 percent) for high-end residential properties. In addition, the Hong Kong Mortgage Corporation announced it was lowering the maximum loan size that could qualify for mortgage insurance and suspending the provision of such insurance for nonowner occupied properties. The authorities emphasized that it was critical to employ a response that was proportional to the potential financial and macroeconomic risks and to avoid a situation where policy actions themselves create market volatility.

\section{B. Exit from Extraordinary Measures}

14. New facilities. In September 2008, as in other jurisdictions, the HKMA lengthened the maturity of discount window operations and expanded the range of eligible collateral. In addition, two new facilities were created to provide foreign exchange swaps and term repos to local banks. In March, the authorities allowed the discount window to return to its previous status as an overnight facility collateralized by Exchange Fund Paper. However, the 
HKMA has chosen to include foreign exchange swaps and term repos as a permanent facility in order to strengthen its lender of last resort toolkit.

15. Deposit guarantee. In October 2008, the authorities introduced a temporary blanket guarantee for all deposits that is set to expire at end-2010. The government will likely exit from its blanket guarantee to a new system with a higher level of deposit coverage (Box 4) and is already making plans to coordinate that exit process with Singapore and Malaysia.

\section{Box 4: Proposed Changes to the Deposit Protection Scheme}

In April 2009, a public consultation was launched to consider potential changes to the existing system of deposit insurance.

The main changes proposed are:

- Coverage limit. Raise the ceiling on deposit protection from $\mathrm{HK} \$ 100,000$ to HK $\$ 500,000$. The new limit would expand coverage to 91 percent of depositors (27 percent of the value of deposits) and around twice the level of per capita GDP. The authorities have undertaken scenario analysis using default probabilities assigned by rating agencies, to examine an adverse scenario with multiple bank failures. Their calculations suggest even the cost of providing protection with a HK $\$ 500,000$ ceiling in such a scenario would still be below the targeted size of the deposit protection fund.

- $\quad$ Netting. The deposit protection scheme would retain full netting, i.e. that all deposit claims are offset against depositor liabilities to the bank in determining entitlement to compensation. There is already in place an information system to ensure such netting can be undertaken smoothly.

- Products. The coverage of deposits will be expanded to include "secured deposits" (i.e., deposits that are pledged as collateral for a credit facility), which are currently outside the deposit protection scheme.

- Institutions. There will be no change in the institutional coverage of the deposit insurance scheme (i.e., to continue to exclude restricted license banks and deposit taking companies).

- $\quad$ Levies. The target size of the deposit protection fund will be reduced to 0.25 percent of total protected deposits (from 0.3 percent currently). The "build-up levies" collected from scheme members (as a share of protected deposits) will be reduced to lessen the burden on scheme members from the higher coverage limits. The scheme will continue to charge higher levies to those banks that have lower supervisory ratings. 
Staff agreed with the planned changes to the deposit insurance system but argued that the authorities should consider moving toward partial netting (by confining the netting of coverage to due and overdue liabilities to the bank) once corresponding changes can be made in the bankruptcy framework. The current system of full netting against all liabilities to the bank has the potential to weaken the deposit protection system and encourage a splitting of loans and deposits across banks. The authorities indicated that the benefits of reducing the scope of netting were expected to be small in Hong Kong SAR's context, since borrowers did not typically have significant deposits in the banks from which they had borrowed. On the other hand, moving to a partial netting system would require making fundamental changes to the insolvency framework in order to make such a system cost feasible. The authorities also noted that, during the public consultation process, there had been little interest expressed in moving away from netting and that there was, as yet, no international standard for any preferred approach to netting.

16. Unwinding quantitative easing. Given the monetary policy outlook in the U.S., the expansion of the HKMA's balance sheet is likely to persist for an extended period.

Eventually, though, these extraordinary conditions will reverse, leading to capital outflows. The exchange rate will move to the weak side of the convertibility band and the HKMA will sell U.S. dollars to absorb Hong Kong dollar liquidity. The authorities indicated that they certainly expected, at some point, foreign currency inflows would turn around. They were fully prepared to handle such an eventuality including, if needed, by intervening on occasion within the convertibility band, in line with the rules of the Linked Exchange Rate System. There was agreement that communicating the authorities' policy actions during this period would be critical in order to avoid any disruptive market movements.

\section{Fiscal Policy}

17. Fiscal stimulus. For the past two years, fiscal policy has been geared toward supporting the economy through a range of temporary tax and fee reductions, as well as assistance to the elderly and low income households. The government has also provided loan guarantees to small and medium enterprises and pushed ahead with several large infrastructure projects. Nevertheless, the faster-than-expected recovery and, particularly, the improvement in asset prices and financial markets (from which a sizable share of revenues is derived) could imply that the fiscal outturn for FY2009/10 will involve a much smaller deficit than planned in the budget. While one could argue there is a role for some fiscal tightening to counter the potential upswing in asset prices, staff viewed that the fragile nature of the global recovery argued for some caution in the pace of withdrawal of fiscal stimulus in the FY2010/11 budget. This was particularly true given the important role fiscal policy has played in preventing the large employment losses that were seen in past downturns. The authorities agreed and indicated that they would potentially continue to provide some degree of fiscal support to the economy in the coming year. They noted, particularly, that the government was already planning to expand capital spending on key infrastructure projects 
over the next several years. A decision on the size of any future fiscal support would be made early next year in the context of the Budget.

18. Budget management. Staff argued that it could be worthwhile to take a broad look at the current system for fiscal management. In particular, there could be scope to strengthen the current process of medium-term expenditure planning, to include a broader narrative alongside the existing intra-year fiscal reporting, and place greater emphasis on the degree to which the budget's social and economic outcomes are achieved (rather than on financial compliance and control). This could enhance expenditure efficiency and provide greater clarity on the intended direction of fiscal policy. The authorities indicated that they welcomed suggestions that could lead to improvements to their monthly and quarterly fiscal reporting and that they were already producing considerable information on performance targets and indicators in their annual budget documents.

19. Healthcare. The public sector pays over half of total healthcare costs (2.6 percent of GDP) and over 90 percent of the cost of in-patient care. Hong Kong SAR's demographics imply that, under the current system, the share of public spending on health is likely to rise steadily in the coming years, putting pressure on the longer-term fiscal position and, ultimately, on the quality of care. The authorities have recently completed an extensive public consultation exercise on the options for healthcare reform. During the consultation process there was broad agreement on the proposed changes to provision of health servicesincluding enhancing primary care, developing the electronic sharing of health records, and encouraging public-private partnerships. The government is already moving ahead to implement such reforms. On financing, there were significant reservations among the public about the adoption of a mandatory scheme. As a result, the government is now developing a voluntary proposal with insurance and savings components, which will be accompanied by subsidies and incentives to encourage participation. Staff argued that, given the high quality of publicly provided care, it would be difficult for a voluntary scheme to significantly reduce the pressure on the fiscal accounts, achieve adequate risk pooling among participants, or prevent households from under-saving for future healthcare needs. Nevertheless, staff continued to support the broad intention to alleviate the burden on the fiscal accounts by moving a portion of the costs of healthcare provision to the private sector.

\section{ThE IMPLICATIONS OF MAINLAND REbalanCING}

20. Impact. The Mainland government has been clear about its intention to shift growth away from exports and high levels of investment toward a greater reliance on household consumption. This has important longer-term implications for Hong Kong SAR since around one-third of its service exports are concentrated in providing logistics, merchandising, and other services related to Mainland trade. As a consumption-based economy develops further on the Mainland, producers there could progressively orient themselves toward the domestic market and Mainland service providers could increasingly compete with Hong Kong entities (particularly in finance, merchandising, and logistics). 
21. Growth strategy. The chief executive's October 14 policy address placed a particular focus on the government's strategy for promoting economic development. He indicated that the government would continue to provide a supportive environment to Hong Kong SAR's traditional key industries (financial services, tourism, trading and logistics, and professional services). In addition, the government intends to seek out ways to foster new service sectors including education, healthcare, testing and certification, environmental industries, innovation and technology, and creative industries. Specific measures include providing land for private, post-secondary education institutions and private hospitals, as well as encouraging the rehabilitation of industrial buildings to meet Hong Kong SAR's changing economic and social needs. The authorities have established a Council for Testing and Certification to enhance professional standards and garner international recognition. The government also plans to expand the incentives on offer for companies undertaking research and development investment.

22. Financial integration with the Mainland. The authorities attach significant importance to the progress that has steadily been made to integrate Hong Kong SAR's financial system with that of the Mainland and develop the offshore renminbi business (Box 5). The authorities saw as particularly encouraging recent steps to permit trade settlement in renminbi between select Mainland enterprises and counterparts in Hong Kong SAR, Macao SAR, and ASEAN countries. They also saw good prospects, over time, for an interbank market to develop which would allow for cross-border renminbi transactions, as well as for renminbi project financing and syndicated renminbi loans.

\section{Box 5: Recent Steps Toward Greater Financial Integration with the Mainland}

Over the past year, there have been significant new developments in the process of integrating Hong Kong SAR's financial system with that of the Mainland, as well as continued progress in various areas. These include:

- In July, the Mainland authorities announced a pilot scheme that would allow eligible enterprises in Shanghai, Guangzhou, Shenzhen, Dongguan, and Zhuhai to settle trade in renminbi with counterparts in Hong Kong SAR, Macao SAR, and ASEAN member countries.

- In October, the Chinese Ministry of Finance issued Y6 billion in sovereign renminbi bonds in Hong Kong SAR, the first issue of its kind outside of the Mainland.

- Mainland banks have continued to issue renminbi bonds in Hong Kong SAR (totaling Y10 billion so far this year) including, in August, two issues of floating rate bonds priced off of SHIBOR.

- After declining since mid-2008, renminbi deposits in Hong Kong banks have begun to pick up in recent months, totaling Y58 billion at end-September.

- Hong Kong banks continue to expand their operations on the Mainland through a broader branch network and subsidiaries. 


\section{Staff Appraisal}

23. Global context. Hong Kong SAR has been hit hard by the global financial crisis. The economy's heavy reliance on trade and financial services made it doubly exposed when, in late 2008, global trade collapsed and extraordinary pressures built in the international financial system. The force of the shock was clearly seen in the severity of the contraction in the first quarter.

24. Economic recovery. The recovery is now underway, fueled by growth in the Mainland, stimulative fiscal policies, the government's efforts to support smaller enterprises and preserve employment, and highly accommodative monetary conditions imported from the U.S. The economy should steadily strengthen - growing at 5 percent in 2010 — and unemployment should decline in the coming months. Nevertheless, the protracted process of recovery in the main industrial economies is likely to mean that the contribution to growth from external demand will remain relatively weak for some time, despite a strong performance in the Mainland. Price pressures should remain muted and, given the current outlook for global commodity prices, consumer price inflation should end 2010 close to zero.

25. Monetary conditions. Over the past several months, nominal Hong Kong dollar interest rates, even at longer maturities, have remained close to zero. In addition, Hong Kong SAR has imported quantitative easing from the U.S. and the HKMA's balance sheet has expanded alongside that of the Federal Reserve. It is likely that such accommodative monetary conditions will remain in place for an extended period, during which time the implications of the resulting high level of liquidity will have to be deftly managed. In addition, at some future point, the recent extraordinary expansion in the Aggregate Balance will be unwound through the HKMA intervening to sell foreign currency and reabsorb local currency liquidity. Clear communication with the public and financial markets during this period will be essential in order to prevent unnecessary turbulence in foreign currency or money markets.

26. Exchange rate regime. The Linked Exchange Rate System merits continued support. It has shown itself to be a simple, transparent exchange rate arrangement that has proven to be an anchor of monetary and financial stability. The Hong Kong dollar continues to be valued broadly in line with economic fundamentals and price flexibility - in goods, factor and asset markets - has acted as a vital mechanism for the real exchange rate to adjust to the recent large external shocks. Maintaining such flexibility going forward will be essential, particularly given the ongoing structural changes in the global economy and in Mainland China. A flexible labor market will be particularly important. The government, therefore, is right to be cautious and to adopt an evidence-based approach in setting the level of the statutory minimum wage.

27. Banking system. The Hong Kong banking system has proved to be resilient to the dramatic events in the global financial system over the past year. The system is healthy, 
liquid, and well capitalized. The level of nonperforming loans remains low, although the economic slowdown has led to some increase, particularly in lending to manufacturing and trade-related sectors. Stress tests suggest that the risks to the banking system remain low, even under an extremely negative scenario. The robustness of the banking system is the product of conscientious and prudent regulation and enforcement, as well as careful risk management by the banks themselves. Bank profits will likely fall in the coming months, a result of higher provisioning and tighter interest margins. Nevertheless, banks should be readily able to absorb this decline in profits.

28. Lender of last resort facilities. The steps taken in September 2008 to put in place supplementary mechanisms for providing liquidity support to the financial system were appropriate. Subsequently, as global financial volatility declined, it was right to return the discount window to its previous status as an overnight facility collateralized by Exchange Fund Paper and to make foreign exchange swaps and term repos a permanent feature of the HKMA's lender of last resort toolkit.

29. Deposit protection. It is clear that Hong Kong SAR is well advanced in planning its exit from the blanket guarantee introduced in October 2008. The proposal to increase the deposit protection limit to a little over twice the level of per capita income is warranted and in line with the coverage in other jurisdictions. Consideration could also be given to, over time, moving away from the current system of netting deposit claims against performing liabilities to the bank. This would further strengthen the protection afforded to depositors. The steps taken by Hong Kong SAR to coordinate with Singapore and Malaysia its exit from the blanket deposit guarantee are commendable.

30. Credit conditions. The extremely expansionary monetary conditions are likely to persist for some time. So far, the large increase in base money has been accompanied by a much more modest growth in credit. Nevertheless, it is possible that, over the next several months, the demand for loans could pick up and, with such a large liquidity overhang in the financial system, credit supply could expand quickly. More credit would fuel asset markets and, in turn, higher asset valuations would provide greater collateral to underpin further borrowing. Such a financial accelerator process has the potential to translate into macroeconomic volatility (in consumption, employment, and consumer prices), particularly given the unprecedented monetary policy easing in the U.S., the scale of inflows coming into Hong Kong SAR, and the differential pace of the recovery in the U.S. and Mainland China.

31. Asset price inflation. There is a concern, therefore, that a credit-asset price cycle could take hold, leading to a sharp run-up in prices for certain real and financial assets. While such asset price movements are part of the natural equilibrating mechanism of the Hong Kong economy, there is a risk that prices could become driven more by short-term liquidity conditions, divorced from fundamental forces of supply and demand. 
32. The policy response. The continued strict enforcement of the existing regulatory regime will certainly be essential in maintaining financial stability and limiting future macroeconomic volatility. In addition, there is a role for the introduction of countervailing prudential measures. Such measures should be simple and transparent and introduced at an early stage in order to make clear what the ground rules are and ensure that the banking industry continues to manage risks prudently. Finally, to moderate potential property price surges, such regulatory policies could be complemented by steps to increase the supply of land to the market.

33. Fiscal policy. In the face of a strong economic downturn, the government announced an expansionary budget earlier this year and a further fiscal package in May. This supplemented the stimulus that was already in train from measures introduced in 2008 . These efforts were fully warranted given the weak economy. The downside risks to the global economy argue for a supportive fiscal stance to be maintained in the upcoming 2010/11 Budget. The government could continue for an additional year with financial assistance for the elderly and low income groups and extend the reduction in the income tax burden for those in the lower income brackets. The government should also press ahead with the major infrastructure projects that have been identified by the chief executive.

34. Fiscal management. In addition to short-term stimulus, the government could also consider further modernizing Hong Kong SAR's systems for budgetary management. A greater focus on assessing social and economic outturns relative to policy goals would provide a useful complement to the extensive information already provided on compliance with the budget's financial targets. In addition, the monthly reports on budgetary outturns could provide more detail in order to allow a more ready assessment of the fiscal position. The government could also begin producing an analytical, mid-year progress report on budget execution to present a broader narrative on the fiscal situation. Finally, the medium term expenditure framework could be strengthened in order to devolve greater authority to government agencies to set medium-term expenditure priorities, supported by measures to increase those agencies' accountability for achieving the government's policy goals.

35. Healthcare. An integral part of any reform should be to safeguard the existing public commitment to support those with chronic or catastrophic illnesses, with disabilities, and those at the lower end of the income distribution. Within that broad guiding principle, efforts should aim to ensure cost containment and increase efficiency. Consideration could be given to the introduction of a broader range of user fees or price-based measures to ensure the efficient use of medical services. Supplementary sources of financing should be phased in at an early stage to ensure that, over time, private financing sources contribute to a larger share of healthcare expenditure. We continue to believe that some form of mandatory healthcare financing scheme will eventually be required.

36. Mainland rebalancing. In the coming years, the Mainland government's goal is to shift growth away from exports and high levels of investment toward a greater reliance on 
household consumption. If this objective is realized, Mainland companies will progressively orient themselves toward a domestic market while increasingly competing with Hong Kong SAR in providing financial, merchandising and logistical services. This provides an important policy challenge but also an opportunity for Hong Kong SAR to seek out new lines of business, particularly as the Mainland economy expands its demand for a range of services.

37. Future growth strategy. The suggestions of the High Level Taskforce provide useful new directions for upgrading the quality and expanding the range of services provided by Hong Kong SAR to the Mainland market. This strategic direction was more fully fleshed out in the chief executive's October 14 policy address. As an important international financial center, Hong Kong SAR certainly has significant potential to provide a range of financial services to the Mainland. In addition, there are opportunities to retool existing trade services including through the provision of greater logistics, marketing and distribution services within the Mainland itself. Hong Kong SAR is also well placed to offer various other services - such as tourism and leisure, healthcare, and higher education - to both Mainland visitors and to the region more broadly. Finally, in line with the direction outlined in the chief executive's policy address, the government should continue to seek out ways to develop Hong Kong SAR as an offshore renminbi business center.

38. It is recommended that the next Article IV consultation take place on the standard 12-month cycle. 
Table 1. Hong Kong SAR: Selected Economic and Financial Indicators, 2006-10 1/

\begin{tabular}{|c|c|c|c|c|c|}
\hline & 2006 & 2007 & 2008 & 2009 & 2010 \\
\hline & & & & \multicolumn{2}{|c|}{ Staff Proj. } \\
\hline Real GDP (percent change) & 7.0 & 6.4 & 2.4 & -2.0 & 5.0 \\
\hline \multicolumn{6}{|l|}{ Contribution } \\
\hline Domestic demand & 5.3 & 6.9 & 0.7 & -0.7 & 4.6 \\
\hline Private consumption & 3.5 & 5.0 & 0.9 & -0.3 & 3.1 \\
\hline Government consumption & 0.0 & 0.2 & 0.1 & 0.6 & 0.6 \\
\hline Gross fixed capital formation & 1.5 & 0.7 & -0.1 & -1.0 & 0.9 \\
\hline Inventories & 0.2 & 0.9 & -0.2 & 0.0 & 0.0 \\
\hline Net exports & 1.7 & -0.6 & 1.6 & -1.3 & 0.4 \\
\hline \multicolumn{6}{|l|}{ Inflation (percent change) } \\
\hline Consumer prices & 2.0 & 2.0 & 4.3 & -1.0 & 0.5 \\
\hline GDP deflator & -0.3 & 2.9 & 1.4 & -0.6 & 2.0 \\
\hline Employment (percent change) & 2.1 & 2.2 & 1.5 & -0.2 & 1.8 \\
\hline Unemployment rate (percent, period average) & 4.8 & 4.0 & 3.5 & 5.1 & 4.8 \\
\hline Real wages & -0.3 & 0.5 & 0.5 & $\ldots$ & $\ldots$ \\
\hline \multicolumn{6}{|l|}{ Government budget (percent of GDP) } \\
\hline Revenue & 19.5 & 22.2 & 18.9 & 17.8 & 16.0 \\
\hline Expenditure & 15.4 & 14.5 & 18.6 & 18.7 & 17.4 \\
\hline Consolidated budget balance & 4.1 & 7.7 & 0.2 & -0.9 & -1.4 \\
\hline Fiscal reserves as of March 31 & 25.0 & 30.5 & 29.5 & 29.2 & 25.8 \\
\hline \multicolumn{6}{|l|}{ Money and credit (percent change, end-period) } \\
\hline Narrow money (M1) & 13.1 & 25.4 & 4.7 & $\ldots$ & $\ldots$ \\
\hline Broad money (M3) & 15.5 & 20.6 & 2.6 & $\ldots$ & $\ldots$ \\
\hline Loans for use in Hong Kong SAR & 2.3 & 15.2 & 11.0 & $\ldots$ & $\ldots$ \\
\hline \multicolumn{6}{|l|}{ Interest rates (percent, end-period) } \\
\hline Best lending rate & 7.8 & 6.8 & 5.0 & $\ldots$ & $\ldots$ \\
\hline Three-month HIBOR & 3.8 & 3.3 & 0.9 & $\ldots$ & $\ldots$ \\
\hline \multicolumn{6}{|l|}{ Asset prices } \\
\hline Hang Seng stock index (end of period, 1964=100) & 19,965 & 27,813 & 14,387 & $\ldots$ & $\ldots$ \\
\hline Hang Seng stock index (percent change) & 34.2 & 39.3 & -48.3 & $\ldots$ & $\ldots$ \\
\hline Residential property prices (end of period, percent change) & 4.1 & 25.7 & -11.1 & $\ldots$ & $\ldots$ \\
\hline \multicolumn{6}{|l|}{ Merchandise trade (percent change) } \\
\hline Export volume & 9.3 & 7.0 & 1.9 & -11.4 & 3.2 \\
\hline Import volume & 9.2 & 8.8 & 1.8 & -10.5 & 2.7 \\
\hline \multicolumn{6}{|l|}{ External balances (percent of GDP) } \\
\hline Merchandise trade balance & -7.4 & -9.5 & -10.7 & -11.0 & -9.5 \\
\hline Domestic exports & 9.4 & 7.3 & 6.1 & 3.1 & 2.8 \\
\hline Re-exports & 157.8 & 159.8 & 163.5 & 149.7 & 149.9 \\
\hline Imports & 174.6 & 176.6 & 180.3 & 163.8 & 162.2 \\
\hline Current account & 12.1 & 12.3 & 14.2 & 11.2 & 11.9 \\
\hline \multicolumn{6}{|l|}{ Foreign exchange reserves $2 /$} \\
\hline In billions of U.S. dollars, end-of-period & 133.2 & 152.7 & 182.5 & 233.4 & 236.8 \\
\hline In months of retained imports & 18.6 & 19.5 & 22.1 & 32.6 & 32.3 \\
\hline In percent of broad money (M3) & 20.3 & 19.4 & 22.6 & $\ldots$ & $\ldots$ \\
\hline \multicolumn{6}{|l|}{ Exchange rate } \\
\hline Linked rate (fixed) & \multicolumn{5}{|c|}{ HK\$7.80/US\$1 } \\
\hline Market rate (HK\$/US\$1, period average) & 7.768 & 7.801 & 7.787 & $\ldots$ & $\ldots$ \\
\hline Real effective rate (period average, $2000=100$ ) $3 /$ & 78.8 & 74.6 & 72.0 & $\ldots$ & $\ldots$ \\
\hline
\end{tabular}

Sources: CEIC Database; and staff estimates and projections.

$1 /$ Unless otherwise stated, all growth rates are for year-on-year. 2/ Includes Land Fund assets.

3/ IMF Staff estimates. 
Table 2. Hong Kong SAR: Consolidated Government Account, 2006/07-2013/14 1/

(In percent of GDP, unless otherwise stated)

\begin{tabular}{|c|c|c|c|c|c|c|c|c|c|c|}
\hline \multirow[b]{3}{*}{ Revenue } & \multirow{3}{*}{$\begin{array}{r}2006 / 07 \\
19.5\end{array}$} & \multirow{3}{*}{$\begin{array}{r}2007 / 08 \\
22.2\end{array}$} & \multicolumn{2}{|c|}{ 2008/09 } & \multirow{2}{*}{$\begin{array}{r}2009 / 10 \\
\text { Budget } 6 /\end{array}$} & \multirow{2}{*}{$\begin{array}{r}2009 / 10 \\
\text { Staff Proj. }\end{array}$} & \multirow[t]{2}{*}{$2010 / 11$} & \multirow{2}{*}{\multicolumn{2}{|c|}{$\frac{2011 / 12 \quad 2012 / 13}{\text { Projections } 7 /}$}} & \multirow[t]{2}{*}{$2013 / 14$} \\
\hline & & & \multicolumn{2}{|l|}{ Budget 6/ } & & & & & & \\
\hline & & & 17.8 & 18.9 & 15.3 & 17.8 & 16.0 & 16.6 & 17.0 & 17.1 \\
\hline Taxes & 12.8 & 14.2 & 10.9 & 13.0 & 10.5 & 12.2 & $\ldots$ & $\ldots$ & $\ldots$ & $\ldots$ \\
\hline Direct taxes & 7.8 & 8.3 & 6.5 & $\ldots$ & 6.6 & 7.2 & $\ldots$ & $\ldots$ & $\ldots$ & $\ldots$ \\
\hline \multicolumn{11}{|l|}{ Of which: } \\
\hline Salaries tax & 2.6 & 2.3 & 1.5 & $\ldots$ & 2.0 & 2.0 & $\ldots$ & $\ldots$ & $\ldots$ & $\ldots$ \\
\hline Profits tax & 4.9 & 5.7 & 4.8 & $\ldots$ & 4.3 & 4.9 & $\ldots$ & $\ldots$ & $\ldots$ & $\ldots$ \\
\hline Indirect taxes & 4.9 & 6.0 & 4.3 & $\ldots$ & 3.9 & 5.0 & $\ldots$ & $\ldots$ & $\ldots$ & $\ldots$ \\
\hline $\begin{array}{l}\text { Nontax } \\
\text { Of which: }\end{array}$ & 6.8 & 7.9 & 7.0 & $\ldots$ & 4.8 & 5.5 & $\ldots$ & $\ldots$ & $\ldots$ & $\ldots$ \\
\hline Land premium & 2.5 & 3.9 & 2.5 & 1.0 & 1.0 & 1.7 & $\ldots$ & $\ldots$ & $\ldots$ & \\
\hline Investment income & 2.0 & 1.7 & 2.5 & 2.8 & 1.9 & 1.9 & 1.3 & 1.1 & 1.1 & 0.8 \\
\hline Expenditure & 15.4 & 14.5 & 18.1 & 18.6 & 18.5 & 18.7 & 17.4 & 17.8 & 17.4 & 17.2 \\
\hline Current 2/ & 13.1 & 12.7 & 12.4 & $\ldots$ & 15.2 & 15.4 & 14.3 & 14.0 & 13.8 & 13.6 \\
\hline \multicolumn{11}{|l|}{ Of which: } \\
\hline Personnel Related & 4.2 & $\ldots$ & $\ldots$ & $\ldots$ & $\ldots$ & $\ldots$ & $\ldots$ & $\ldots$ & $\ldots$ & \\
\hline Capital & 2.2 & 1.9 & 5.7 & $\ldots$ & 3.3 & 3.3 & 3.2 & 3.8 & 3.6 & 3.5 \\
\hline Overall balance & 4.1 & 7.7 & -0.3 & 0.2 & -3.2 & -0.9 & -1.4 & -1.2 & -0.5 & -0.1 \\
\hline \multicolumn{11}{|l|}{ Memorandum items: } \\
\hline Operating balance $3 /$ & 2.7 & 1.2 & 5.4 & 1.4 & -1.0 & 1.4 & -0.8 & -0.2 & 0.3 & 0.7 \\
\hline Primary balance 4/ & 2.2 & 6.0 & -2.8 & -2.5 & -5.1 & -2.7 & -2.7 & -2.3 & -1.5 & -0.9 \\
\hline Structural balance 5 / & 0.3 & 1.6 & $\ldots$ & -0.2 & $\ldots$ & -3.6 & -3.6 & -3.8 & -2.6 & -1.9 \\
\hline Fiscal reserves & 25.0 & 30.5 & 28.1 & 29.5 & 25.2 & 29.2 & 25.8 & 23.4 & 21.8 & 20.7 \\
\hline (Months of spending) & 19.5 & 25.2 & 18.5 & 19.0 & 16.3 & 18.8 & 17.8 & 15.7 & 15.0 & 14.5 \\
\hline
\end{tabular}

Sources: CEIC Database; and staff estimates.

$1 /$ Fiscal year begins on April 1.

2/ This refers to the authorities' measure of operating expenditure.

$3 /$ Operating balance, as defined by the authorities, is akin to the current balance.

4/ Balance excluding investment income.

5/ Staff estimate used to measure the impact of fiscal policy on domestic demand. It excludes asset transactions and cyclical fluctuations.

6/ The "budget estimate" includes the fiscal stimulus package announced in July 2008 and May 2009.

7/Government medium-range budget forecast and staff GDP forecast. 
Table 3. Hong Kong SAR: Medium-Term Balance of Payments, 2006-14

\begin{tabular}{|c|c|c|c|c|c|c|c|c|c|}
\hline & & & & \multicolumn{6}{|c|}{ Projections } \\
\hline & 2006 & 2007 & 2008 & 2009 & 2010 & 2011 & 2012 & 2013 & 2014 \\
\hline & \multicolumn{9}{|c|}{ (In billions of U.S. dollars) } \\
\hline Current account & 22.9 & 25.5 & 30.5 & 23.5 & 26.8 & 26.2 & 25.1 & 22.7 & 20.8 \\
\hline Goods balance & -14.0 & -19.7 & -23.1 & -23.3 & -21.4 & -24.6 & -27.4 & -33.0 & -37.7 \\
\hline Services balance & 35.7 & 42.1 & 46.5 & 43.3 & 44.1 & 46.1 & 47.0 & 49.5 & 50.5 \\
\hline Income balance & 3.5 & 5.7 & 10.5 & 7.0 & 7.7 & 8.6 & 9.5 & 10.5 & 12.3 \\
\hline Transfer balance & -2.2 & -2.6 & -3.3 & -3.5 & -3.7 & -3.9 & -4.1 & -4.3 & -4.3 \\
\hline Capital and financial account & -27.0 & -33.2 & -27.7 & -31.5 & -26.8 & -26.2 & -25.1 & -22.7 & -20.8 \\
\hline Capital account & -0.4 & 1.3 & 2.2 & 1.2 & 1.1 & 1.2 & 1.0 & 1.1 & 1.1 \\
\hline Financial account & -26.7 & -34.6 & -29.9 & -32.8 & -27.9 & -27.4 & -26.1 & -23.8 & -21.9 \\
\hline Net direct investment & 0.1 & -6.7 & 3.1 & -2.0 & -2.4 & -4.6 & -5.7 & -8.3 & -11.0 \\
\hline Inflow & 45.1 & 54.3 & 63.0 & 34.7 & 32.8 & 38.6 & 33.7 & 38.3 & 41.5 \\
\hline Outflow & -45.0 & -61.1 & -59.9 & -36.7 & -35.2 & -43.2 & -39.4 & -46.6 & -52.5 \\
\hline Portfolio investment & -26.8 & -2.7 & -37.6 & -1.7 & -42.1 & -38.5 & -29.5 & -27.2 & -24.6 \\
\hline Financial derivatives & 3.3 & 5.6 & 8.2 & 5.4 & 5.5 & 7.3 & 7.2 & 9.1 & 11.0 \\
\hline Other investment & 2.7 & -16.0 & 30.3 & 16.4 & 14.5 & 16.4 & 13.8 & 15.1 & 15.8 \\
\hline Reserve assets (net change) & -6.0 & -14.7 & -33.9 & -50.9 & -3.4 & -8.0 & -11.9 & -12.5 & -13.0 \\
\hline Net errors and omissions & 4.1 & 7.7 & -2.8 & 8.0 & 0.0 & 0.0 & 0.0 & 0.0 & 0.0 \\
\hline Memorandum items: & \multicolumn{9}{|c|}{ (In percent of GDP) } \\
\hline Current account & 12.1 & 12.3 & 14.2 & 11.2 & 11.9 & 11.1 & 10.1 & 8.7 & 7.6 \\
\hline Goods balance & -7.4 & -9.5 & -10.7 & -11.0 & -9.5 & -10.4 & -11.0 & -12.6 & -13.7 \\
\hline Services balance & 18.8 & 20.3 & 21.6 & 20.5 & 19.6 & 19.4 & 18.9 & 18.9 & 18.4 \\
\hline Income balance & 1.9 & 2.8 & 4.9 & 3.3 & 3.4 & 3.6 & 3.8 & 4.0 & 4.5 \\
\hline Transfer balance & -1.2 & -1.2 & -1.5 & -1.7 & -1.6 & -1.6 & -1.6 & -1.6 & -1.6 \\
\hline Capital and financial account & -14.2 & -16.0 & -12.9 & -15.0 & -11.9 & -11.1 & -10.1 & -8.7 & -7.6 \\
\hline Capital account & -0.2 & 0.6 & 1.0 & 0.6 & 0.5 & 0.5 & 0.4 & 0.4 & 0.4 \\
\hline Financial account & -14.0 & -16.7 & -13.9 & -15.5 & -12.4 & -11.6 & -10.5 & -9.1 & -8.0 \\
\hline Net direct investment & 0.0 & -3.3 & 1.4 & -0.9 & -1.1 & -1.9 & -2.3 & -3.2 & -4.0 \\
\hline Portfolio investment & -14.1 & -1.3 & -17.4 & -0.8 & -18.7 & -16.2 & -11.9 & -10.4 & -9.0 \\
\hline Financial derivatives & 1.8 & 2.7 & 3.8 & 2.5 & 2.5 & 3.1 & 2.9 & 3.5 & 4.0 \\
\hline Other investment & 1.4 & -7.7 & 14.1 & 7.8 & 6.4 & 6.9 & 5.5 & 5.8 & 5.7 \\
\hline Reserve assets (net change) & -3.2 & -7.1 & -15.7 & -24.2 & -1.5 & -3.4 & -4.8 & -4.8 & -4.7 \\
\hline Net errors and omissions & 2.2 & 3.7 & -1.3 & 3.8 & 0.0 & 0.0 & 0.0 & 0.0 & 0.0 \\
\hline
\end{tabular}

Sources: CEIC Database; and staff estimates. 
Table 4. Hong Kong SAR: Medium-Term Macroeconomic Framework, 2006-14

\begin{tabular}{|c|c|c|c|c|c|c|c|c|c|}
\hline & \multirow[b]{2}{*}{2006} & \multirow[b]{2}{*}{2007} & \multirow[b]{2}{*}{2008} & \multicolumn{4}{|c|}{ Staff Projections } & \multirow[b]{2}{*}{2013} & \multirow[b]{2}{*}{2014} \\
\hline & & & & 2009 & 2010 & 2011 & 2012 & & \\
\hline Real GDP (percent change) & 7.0 & 6.4 & 2.4 & -2.0 & 5.0 & 4.4 & 4.3 & 4.3 & 4.3 \\
\hline \multicolumn{10}{|l|}{ Contribution } \\
\hline Real domestic demand & 5.3 & 6.9 & 0.7 & -0.7 & 4.6 & 3.9 & 3.7 & 3.8 & 3.7 \\
\hline Private consumption & 3.5 & 5.0 & 0.9 & -0.3 & 3.1 & 3.0 & 3.4 & 3.0 & 2.8 \\
\hline Government consumption & 0.0 & 0.2 & 0.1 & 0.6 & 0.6 & -0.4 & -0.4 & -0.4 & -0.3 \\
\hline Gross fixed capital formation & 1.5 & 0.7 & -0.1 & -1.0 & 0.9 & 1.3 & 0.8 & 1.2 & 1.2 \\
\hline Inventories & 0.2 & 0.9 & -0.2 & 0.0 & 0.0 & 0.0 & 0.0 & 0.0 & 0.0 \\
\hline Net exports & 1.7 & -0.6 & 1.6 & -1.3 & 0.4 & 0.6 & 0.6 & 0.4 & 0.6 \\
\hline Output gap (in percent of potential) & 1.7 & 2.8 & 0.1 & -5.0 & -2.9 & -1.9 & -0.9 & -0.4 & -0.4 \\
\hline \multicolumn{10}{|l|}{ Growth rates } \\
\hline Real domestic demand & 5.9 & 7.9 & 0.8 & -0.7 & 5.2 & 4.3 & 4.2 & 4.3 & 4.1 \\
\hline Private consumption & 5.9 & 8.5 & 1.5 & -0.5 & 5.2 & 5.0 & 5.5 & 4.9 & 4.5 \\
\hline Government consumption & 0.3 & 3.0 & 1.7 & 8.0 & 6.5 & -5.0 & -5.0 & -5.0 & -5.0 \\
\hline Gross fixed capital formation & 7.1 & 3.4 & -0.5 & -5.1 & 4.8 & 6.7 & 4.0 & 6.2 & 6.3 \\
\hline \multicolumn{10}{|l|}{ Saving and investment (percent of GDP) } \\
\hline Gross national saving & 33.8 & 33.3 & 34.5 & 31.0 & 31.5 & 31.3 & 30.5 & 29.7 & 29.2 \\
\hline Gross investment & 21.7 & 20.9 & 20.4 & 19.8 & 19.6 & 20.3 & 20.4 & 21.0 & 21.7 \\
\hline Saving-investment balance & 12.1 & 12.3 & 14.2 & 11.2 & 11.9 & 11.1 & 10.1 & 8.7 & 7.6 \\
\hline \multicolumn{10}{|l|}{ Inflation (percent change) } \\
\hline Consumer prices & 2.0 & 2.0 & 4.3 & -1.0 & 0.5 & 1.5 & 1.8 & 2.2 & 2.6 \\
\hline GDP deflator & -0.3 & 2.9 & 1.4 & -0.6 & 2.0 & 0.7 & 0.6 & 0.7 & 0.8 \\
\hline Employment (percent change) & 2.1 & 2.2 & 1.5 & -0.2 & 1.8 & 1.7 & 1.8 & 1.8 & 1.7 \\
\hline Unemployment rate (percent) & 4.8 & 4.0 & 3.5 & 5.1 & 4.8 & 4.6 & 4.3 & 4.0 & 3.8 \\
\hline Real wages & -0.3 & 0.5 & 0.5 & $\cdots$ & $\cdots$ & $\cdots$ & $\cdots$ & $\cdots$ & $\cdots$ \\
\hline \multicolumn{10}{|l|}{ Merchandise trade (percent change) } \\
\hline Export volume & 9.3 & 7.0 & 1.9 & -11.4 & 3.2 & 7.9 & 8.8 & 8.9 & 8.9 \\
\hline o/w Re-exports & 9.7 & 8.6 & 2.9 & -10.1 & 3.4 & 8.1 & 9.0 & 9.0 & 9.0 \\
\hline Import volume & 9.2 & 8.8 & 1.8 & -10.5 & 2.7 & 7.6 & 8.2 & 8.8 & 8.4 \\
\hline Export value & 9.6 & 9.4 & 5.4 & -12.2 & 7.0 & 10.7 & 8.0 & 8.9 & 7.9 \\
\hline Import value & 11.5 & 10.7 & 6.0 & -11.5 & 6.0 & 11.0 & 8.2 & 9.6 & 8.4 \\
\hline \multicolumn{10}{|l|}{ External balances (in billions of US\$) } \\
\hline Trade balance & -14.0 & -19.7 & -23.1 & -23.3 & -21.4 & -24.6 & -27.4 & -33.0 & -37.7 \\
\hline In percent of GDP & -7.4 & -9.5 & -10.7 & -11.0 & -9.5 & -10.4 & -11.0 & -12.6 & -13.7 \\
\hline Exports of goods & 318 & 346 & 365 & 322 & 345 & 382 & 412 & 449 & 484 \\
\hline Imports of goods & 332 & 366 & 388 & 345 & 366 & 406 & 439 & 482 & 522 \\
\hline Current account & 22.9 & 25.5 & 30.5 & 23.5 & 26.8 & 26.2 & 25.1 & 22.7 & 20.8 \\
\hline In percent of GDP & 12.1 & 12.3 & 14.2 & 11.2 & 11.9 & 11.1 & 10.1 & 8.7 & 7.6 \\
\hline Foreign exchange reserves (end-year) & 133.2 & 152.7 & 182.5 & 233.4 & 236.8 & 244.8 & 256.7 & 269.2 & 282.2 \\
\hline In percent of GDP & 70.1 & 73.7 & 84.8 & 110.8 & 104.9 & 103.2 & 103.1 & 103.0 & 102.7 \\
\hline
\end{tabular}

Sources: CEIC Database; and staff estimates and projections. 
Table 5. Hong Kong SAR: Vulnerability Indicators, 2000-09

\begin{tabular}{|c|c|c|c|c|c|c|c|c|c|c|}
\hline & 2000 & 2001 & 2002 & 2003 & 2004 & 2005 & 2006 & 2007 & 2008 & $\begin{array}{r}2009 \\
\text { Latest }\end{array}$ \\
\hline \multicolumn{11}{|l|}{ Public sector } \\
\hline Fiscal deficit (in percent of GDP) & -0.6 & -4.9 & -4.8 & -3.2 & -0.3 & 1.0 & 4.1 & 7.7 & 0.2 & -8.9 \\
\hline Accumulated fiscal surplus (in percent of GDP) & 32.7 & 28.7 & 24.4 & 22.3 & 22.9 & 22.5 & 25.0 & 30.5 & 29.5 & 28.0 \\
\hline \multicolumn{11}{|l|}{ External sector } \\
\hline Total export volume (percent change) & 16.9 & -3.3 & 8.6 & 14.0 & 14.9 & 10.4 & 9.3 & 7.0 & 1.9 & -12.4 \\
\hline Domestic exports & 8.2 & -10.0 & -11.0 & -6.9 & 2.2 & 6.1 & 3.0 & -19.3 & -19.2 & -28.3 \\
\hline Re-exports & 18.1 & -2.3 & 10.9 & 15.9 & 15.8 & 10.7 & 9.7 & 8.6 & 2.9 & -11.9 \\
\hline Total import volume (percent change) & 18.4 & -1.9 & 7.9 & 13.1 & 13.7 & 8.0 & 9.2 & 8.8 & 1.8 & -12.7 \\
\hline Current account (in billions of U.S. dollar) & 7.0 & 9.8 & 12.4 & 16.5 & 15.7 & 20.2 & 22.9 & 25.5 & 30.5 & 5.9 \\
\hline Net equity inflow (in billions of U.S. dollar) & 29.4 & -23.5 & -14.4 & -4.2 & -28.5 & -18.0 & -1.2 & -25.7 & -4.3 & -4.2 \\
\hline Gross official reserves (in billions of U.S. dollar) & 107.6 & 111.2 & 111.9 & 118.4 & 123.6 & 124.3 & 133.2 & 152.7 & 182.5 & 223.3 \\
\hline In months of retained imports & 18.0 & 20.4 & 22.6 & 23.3 & 21.2 & 19.8 & 18.6 & 19.5 & 22.1 & 28.7 \\
\hline In percent of monetary base & 388.7 & 377.0 & 354.0 & 314.6 & 325.7 & 340.1 & 349.3 & 371.6 & 280.1 & 218.3 \\
\hline In percent of broad money $1 /$ & 23.0 & 24.4 & 24.8 & 24.2 & 23.1 & 22.1 & 20.5 & 19.5 & 22.7 & 26.6 \\
\hline In percent of Hong Kong dollar M3 & 41.9 & 43.0 & 43.5 & 43.4 & 43.4 & 41.2 & 37.0 & 36.1 & 43.6 & 49.6 \\
\hline Short-term debt (in billions of U.S. dollar) 2/ & $\ldots$ & 300.0 & 223.8 & 250.5 & 308.5 & 310.5 & 364.8 & 539.8 & 483.9 & 473.2 \\
\hline In percent of gross reserves & $\ldots$ & 269.9 & 200.0 & 211.6 & 249.6 & 249.8 & 273.9 & 353.5 & 265.1 & 228.6 \\
\hline One-year forward exchange rate premium (in pips, annual average) & -35.5 & 52.7 & 138.8 & 33.9 & -704.8 & -448.9 & -599.7 & -552.3 & -337.4 & -146.8 \\
\hline Real exchange rate (percent change) & -3.2 & 0.3 & -4.8 & -9.0 & -6.6 & -2.1 & -0.9 & -5.3 & -3.4 & 6.4 \\
\hline \multicolumn{11}{|l|}{ Financial sector } \\
\hline HIBOR(3M)-LIBOR(3M) (in basis points, per annum) & -44.0 & -3.9 & 0.6 & -25.0 & -128.9 & -64.6 & -102.4 & -100.3 & -51.9 & -34.6 \\
\hline Hang Seng index (percent change, end-year) $3 /$ & -11.0 & -24.5 & -18.2 & 34.9 & 13.2 & 4.5 & 34.2 & 39.3 & -48.3 & 45.6 \\
\hline Residential property prices (percent change, end-year) $3 /$ & -14.5 & -9.8 & -12.2 & 0.9 & 27.4 & 8.2 & 4.1 & 25.7 & -11.1 & 20.4 \\
\hline \multicolumn{11}{|l|}{ Banking sector $4 /$} \\
\hline Deposit-loans ratio $5 /$ & 143.3 & 155.9 & 159.8 & 175.3 & 179.3 & 175.9 & 192.8 & 198.2 & 184.4 & 198.3 \\
\hline Domestic credit growth 6/ & 2.3 & -3.8 & -2.6 & -2.0 & 4.9 & 7.7 & 2.3 & 15.2 & 11.0 & -5.0 \\
\hline Real credit growth & 4.5 & -0.3 & -1.2 & -0.1 & 4.6 & 6.2 & 0.0 & 11.0 & 8.8 & -3.5 \\
\hline Capital adequacy ratio 7/ & 17.9 & 16.5 & 15.7 & 15.3 & 15.4 & 14.8 & 14.9 & 13.4 & 14.8 & 16.5 \\
\hline Nonperforming loans (in percent of total loans) $8 / 9$ / & 7.3 & 6.5 & 5.0 & 3.9 & 2.3 & 1.4 & 1.1 & 0.8 & 1.2 & 1.5 \\
\hline Net interest margin (in percent of interest-bearing assets) 9/ & 2.1 & 2.0 & 2.1 & 1.9 & 1.7 & 1.7 & 1.8 & 1.9 & 1.8 & 1.6 \\
\hline Return on assets (post-tax) $9 /$ & 1.2 & 1.0 & 1.2 & 1.2 & 1.4 & 1.4 & 1.4 & 1.5 & 0.9 & $\ldots$ \\
\hline Net open spot position (in billions of U.S. dollar) & 25.7 & 24.7 & 18.2 & 15.9 & 28.2 & 30.7 & 52.0 & 78.8 & 57.1 & 40.8 \\
\hline Net open forward position (in billions of U.S. dollar) & -18.7 & -14.6 & -6.7 & -6.4 & -24.5 & -25.9 & -46.2 & -71.8 & -44.0 & -27.0 \\
\hline Exposure to the Mainland (in percent of total assets) & 2.9 & 2.4 & 2.2 & 2.0 & 2.3 & 2.6 & 5.9 & 6.5 & 7.1 & 7.2 \\
\hline Exposure to property sector (in percent of domestic credit) $10 /$ & 49.2 & 51.0 & 52.1 & 51.3 & 50.6 & 50.5 & 51.2 & 49.3 & 49.8 & 50.6 \\
\hline Deposits (in percent of liabilities) & 53.0 & 55.4 & 55.3 & 55.0 & 54.2 & 56.1 & 57.3 & 56.7 & 56.3 & 60.3 \\
\hline \multicolumn{11}{|l|}{ Contagion indicator } \\
\hline HK\$-renminbi forward exchange rate correlation (daily) & -0.1 & 0.1 & -0.1 & 0.9 & 0.8 & 0.7 & -0.4 & 0.5 & -0.4 & -0.4 \\
\hline Hang Seng-NASDAQ correlation (daily) & 0.7 & 0.9 & 0.8 & 0.9 & 0.6 & 0.8 & 0.5 & 0.8 & 0.9 & 0.9 \\
\hline
\end{tabular}

Sources: CEIC Database; Hong Kong SAR authorities; Bank for International Settlements; and staff estimates.

$1 /$ Broad Money refers to M2.

2/ Official statistics on Hong Kong SAR's external debt are available from the first quarter of 2002.

3/ Refers to year-to-date change since end of previous year.

4/ For all authorized institutions, unless otherwise specified.

5/ Figures have been revised due to a change in the definition of customer deposits to include short-term Exchange Fund placements.

6/ Domestic credit refers to loans for use in Hong Kong SAR.

7/ For all locally incorporated authorized institutions.

8/ Refers to total gross classified: "substandard," "doubtful," and "loss."

9/ For retail banks, which comprise all the locally incorporated banks plus a number of the larger foreign banks whose operations are similar to those of the locally incorporated banks, in that they operate a branch network and are active in retail banking.

$10 /$ Exposure to property sector includes loans to finance property investment and development as well as residential mortgage loans. 


\section{INTERNATIONAL MONETARY FUND \\ PEOPLE'S REPUBLIC OF CHINA-HONG KONG \\ SPECIAL ADMINISTRATIVE REGION \\ Staff Report for the 2009 Article IV Consultation \\ Discussions-Informational Annex}

Prepared by the Asia and Pacific Department

November 3, 2009

Contents

Page

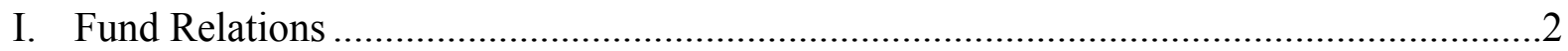

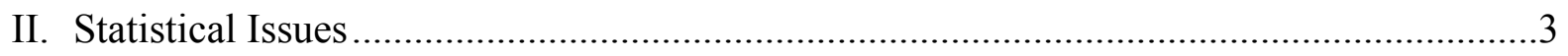




\section{ANNEX I: Hong KONG SAR—FUnd RELATIONS}

\section{Membership Status}

As a Special Administrative Region of the People's Republic of China, Hong Kong SAR is not a member of the Fund. However, annual consultation discussions have been held with the Hong Kong SAR authorities since October 1990, and the staff also holds discussions with the authorities in connection with the Fund' Global Financial Stability reports. STA has provided Hong Kong SAR with technical assistance in the area of balance of payments statistics and Hong Kong SAR officials have attended IMF Institute courses on balance of payments and monetary statistics, and financial programming.

\section{Exchange Rate Arrangement}

The Hong Kong dollar has been linked to the U.S. dollar under a currency board arrangement since October 1983 at a rate of HK\$7.8/US\$1. The Hong Kong Monetary Authority (HKMA) refined the operations of the LERS in May 2005 - the first changes since September 1998. For the first time since the introduction of the LERS in 1983, the HKMA explicitly committed to sell Hong Kong dollar at a pre-announced price (set at HK\$7.75/US\$), which is referred to as the strong-side convertibility undertaking. Previously, the HKMA had only committed to buy Hong Kong dollar at a pre-announced rate (the weak-side convertibility undertaking introduced in October 1998) and could sell Hong Kong dollar at any price. Along with this two-way convertibility undertaking, the HKMA also introduced a symmetric trading band of 0.6 percent around a central parity of HK $\$ 7.8 / \mathrm{US} \$$. There are no restrictions on current or capital account transactions in Hong Kong SAR, and the Hong Kong dollar is freely convertible. The People's Republic of China accepted the obligations under Article VIII, Sections 2, 3, and 4 of the Articles of Agreement on December 1, 1996.

\section{Resident Representative}

The Hong Kong SAR sub-office of the Beijing Resident Representative's office was opened on September 23, 2000. Mr. Vivek Arora is resident representative. 


\section{ANNEX II: Hong Kong SAR-STATISTICAL ISSUES}

Data provision is adequate for surveillance purposes. Hong Kong SAR provides statistics to the Fund on a timely basis for surveillance and publication in the International Financial Statistics (IFS). Hong Kong SAR subscribes to the Fund's Special Data Dissemination Standard and is fully compliant with its requirements.

Hong Kong SAR publishes comprehensive balance of payments data and international investment position statistics for 2000 onwards, and also publishes quarterly external debt statistics according to the recommendations given in the External Debt Statistics: Guide for Compilers and Users.

Hong Kong SAR reports both cash and accrual-based annual data for the general government according to the Fund's Government Finance Statistics Manual (GFSM 2001). No subannual data are provided for publication in the IFS.

Hong Kong SAR participated in the IMF's Coordinated Compilation Exercise for Financial Soundness Indicators (FSIs) and its FSI data and metadata for 2005 have been posted on the IMF website.

Work is in progress on the compilation of monetary statistics using the Standardized Report Forms that present data consistent with the Monetary and Financial Statistics Manual. 
HONG KONg SAR-TABLE OF COMMON INDICATORS REQUIRED FOR SURVEILLANCE

As of October 8, 2009

\begin{tabular}{|c|c|c|c|c|c|}
\hline & $\begin{array}{c}\text { Date of } \\
\text { Latest } \\
\text { Observation }\end{array}$ & $\begin{array}{l}\text { Date } \\
\text { Received }\end{array}$ & $\begin{array}{c}\text { Frequency } \\
\text { of } \\
\text { Data }^{5}\end{array}$ & $\begin{array}{l}\text { Frequency } \\
\text { of } \\
\text { Reporting }^{5}\end{array}$ & $\begin{array}{l}\text { Frequency } \\
\text { of } \\
\text { Publication }^{5}\end{array}$ \\
\hline Exchange rates & $10 / 08 / 09$ & 10/08/09 & $\mathrm{D}$ & $\mathrm{D}$ & $\mathrm{D}$ \\
\hline $\begin{array}{l}\text { International reserve assets and reserve } \\
\text { liabilities of the monetary authorities }{ }^{1}\end{array}$ & $08 / 09$ & $10 / 09$ & M & M & M \\
\hline Reserve/base money & $08 / 09$ & $10 / 09$ & M & M & $M$ \\
\hline Broad money & 08/09 & $10 / 09$ & M & M & $M$ \\
\hline Central bank balance sheet & $08 / 09$ & $10 / 09$ & M & M & M \\
\hline $\begin{array}{l}\text { Consolidated balance sheet of the banking } \\
\text { system }\end{array}$ & $08 / 09$ & $10 / 09$ & M & M & M \\
\hline Interest rates ${ }^{2}$ & 10/08/09 & 10/08/09 & $\mathrm{D}$ & $\mathrm{D}$ & $\mathrm{D}$ \\
\hline Consumer price index & 08/09 & $10 / 09$ & M & M & M \\
\hline $\begin{array}{l}\text { Revenue, expenditure, balance and } \\
\text { composition of financing }{ }^{3}-\text { central } \\
\text { government }\end{array}$ & 08/09 & $10 / 09$ & M & M & M \\
\hline $\begin{array}{l}\text { Stocks of central government and central } \\
\text { government-guaranteed } \text { debt }^{4}\end{array}$ & 08/09 & $10 / 09$ & M & M & $M$ \\
\hline External current account balance & Q2/09 & $10 / 09$ & Q & Q & Q \\
\hline Exports and imports of goods and services & Q2/09 & $10 / 09$ & Q & Q & Q \\
\hline GDP/GNP & Q2/09 & $10 / 09$ & Q & Q & Q \\
\hline Gross external debt & Q2/09 & $10 / 09$ & Q & Q & Q \\
\hline International investment position & 2008 & $10 / 09$ & A & A & A \\
\hline
\end{tabular}

${ }^{1}$ Includes reserve assets pledged or otherwise encumbered as well as net derivative positions.

2 Both market-based and officially-determined, including discount rates, money market rates, rates on treasury bills, notes and bonds.

${ }^{3}$ Foreign, domestic bank, and domestic nonbank financing.

${ }^{4}$ Including currency and maturity composition.

${ }^{5}$ Daily (D), Weekly (W), Monthly (M), Quarterly (Q), Annually (A); Irregular (I); Not Available (NA). 


\section{Statement by the IMF Staff Representative on November 23, 2009}

The information below, which has become available following the issuance of the staff report, does not alter the thrust of the staff appraisal.

1. GDP data for the third quarter was released on November 13. The data was weaker than staff had anticipated and was particularly hard hit by a fall in net exports of goods (which detracted 10 percentage points from the seasonally adjusted quarter-on-quarter growth rate). Domestic consumption and investment, however, strengthened during the quarter, offsetting some of the drag from external demand. In addition, there was a significant build-up of inventories toward the end of the quarter.

2. The weaker-than-expected GDP outturn indicates that the staff's forecast of a 2 percent contraction for this year may prove optimistic. However, this data does underscore that the downside risks to growth from external demand are significant and a supportive fiscal stance should be maintained in the FY 2010/11 Budget.

Hong Kong SAR: Contributions to GDP Growth

\begin{tabular}{lcccrr}
\hline & 2007 & 2008 & \multicolumn{3}{c}{2009} \\
\cline { 5 - 6 } & & & Q1 & Q2 & Q3 \\
\hline GDP & 6.4 & 2.4 & -4.3 & 3.5 & 0.4 \\
Consumption & 5.3 & 1.0 & -1.2 & 2.5 & 0.4 \\
Investment & 1.7 & -0.3 & -1.8 & 0.6 & 8.5 \\
Net exports & -0.6 & 1.6 & -1.3 & 0.3 & -8.6 \\
Of which: & & & & & \\
$\quad$ Goods & -3.6 & 0.0 & -0.1 & 0.0 & -10.1 \\
$\quad$ Services & 3.0 & 1.6 & -1.3 & 0.3 & 1.5 \\
Memo item: & & & & & \\
Changes in inventories (nsa) & 0.9 & -0.2 & -2.1 & 0.6 & 6.1 \\
\hline Sources: CEIC Database; and staff estimates. & & & & &
\end{tabular}

3. In August to October, the seasonally adjusted unemployment rate fell to 5.2 percent (from 5.3 percent in July to September). However, it is worth noting that, on a nonseasonally adjusted basis, the decline in the number of unemployed came from a fall in labor force participation rather than an expansion of employment.

4. The Hong Kong Monetary Authority (HKMA) has continued to intervene to purchase foreign currency in accordance with the design of the Linked Exchange Rate System. From November 1 to 19 the HKMA purchased US\$11.9 billion in foreign currency as the Hong Kong dollar hit the strong side of the convertibility band. 


\section{INTERNATIONAL MONETARY FUND}

Public Information Notice (PIN) No. 09/130

FOR IMMEDIATE RELEASE

December 2, 2009
International Monetary Fund

$70019^{\text {th }}$ Street, NW

Washington, D. C. 20431 USA

\section{IMF Executive Board Concludes 2009 Article IV Consultation Discussions with People's Republic of China-Hong Kong Special Administrative Region}

On November 23, 2009, the Executive Board of the International Monetary Fund (IMF) concluded the Article IV consultation discussions with People's Republic of ChinaHong Kong Special Administrative Region (SAR). ${ }^{1}$

\section{Background}

Hong Kong SAR's economy was severely affected by the global financial crisis (through both trade and financial channels) but a recovery is now underway, fueled by growth on the Mainland, supportive policies, and accommodative monetary conditions imported from the United States. Despite the steepness of the downturn in early 2009, job losses have been relatively modest and unemployment now stands at 5.2 percent (in seasonally adjusted terms, August to October). Headline inflation has declined due to lower food inflation and the direct effects of fiscal measures (such as the reductions in rates and public housing rent). Weak services exports and income flows have narrowed the current account surplus to around 111/2 percent of GDP in the first half of 2009. Nevertheless, significant capital inflows have led to an increase in official reserves to around US $\$ 223$ billion by end-August.

\footnotetext{
${ }^{1}$ Under Article IV of the IMF's Articles of Agreement, the IMF holds bilateral discussions with members, usually every year. A staff team visits the country, collects economic and financial information, and discusses with officials the country's economic developments and policies. On return to headquarters, the staff prepares a report, which forms the basis for discussion by the Executive Board. At the conclusion of the discussion, the Managing Director, as Chairman of the Board, summarizes the views of Executive Directors, and this summary is transmitted to the country's authorities. An explanation of any qualifiers used in summings up can be found here: http://www.imf.org/external/np/sec/misc/qualifiers.htm..
} 
In February, the government announced an expansionary budget with a deficit of HK\$39.9 billion. In May, the budget was supplemented with a further HK\$16.8 billion (1 percent of GDP) fiscal package. The government has also provided loan guarantees to help alleviate the tightening of credit conditions experienced by small- and mediumsized companies, particularly in late 2008. These loan guarantee schemes secured more than 240,000 jobs. The combined discretionary policy stimulus taken since 2008-09 (excluding the additional commitment of about HK\$107.4 billion under the various loan guarantee schemes) amounts to over 5 percent of GDP.

The Hong Kong financial system has withstood the downturn well. Banks were generally not exposed to the securitized products at the center of the crisis in the U.S., had good internal risk management systems, were highly liquid, and had low loan-to-deposit ratios. Average capital adequacy ratios were 161/2 percent at end-June with around three-fourths of that being in the form of Tier 1 capital. Banking system profitability has declined due to higher provisioning and tighter interest margins and the economic slowdown has worsened credit quality, particularly on lending to small- and mediumsized enterprises. Nevertheless, nonperforming loans remain at low levels (classified loans were $1 \frac{1}{2}$ percent of the total in June).

\section{Executive Board Assessment}

The Executive Directors observed that Hong Kong SAR had been severely affected by the global financial crisis, resulting in a sharp economic contraction in early 2009 . The swift, broad-based policy efforts taken by the authorities, particularly a sizeable fiscal stimulus package, coupled with accommodative monetary conditions, have facilitated a rapid turnaround. Growth is expected to strengthen steadily and unemployment to decline in the coming months. Nevertheless, the outlook is subject to downside risks, including a weaker-than-expected recovery in Hong Kong SAR's major trading partners.

Directors noted that strong capital inflows and the resultant large liquidity overhang in the financial system could potentially lead to rapid credit growth, fueling asset markets and creating macroeconomic volatility. They welcomed the authorities' contingency strategy to pre-empt asset price bubbles, as well as ongoing efforts to increase the availability of land. Strict enforcement of the existing regulatory regime would be essential, while countervailing prudential measures could play a role in mitigating the credit-asset price cycle. Directors emphasized that, when liquidity conditions and pressures on the currency eventually reverse, clear communication of policy actions by the monetary authorities will be important.

Directors generally considered that the Linked Exchange Rate System remains appropriate for Hong Kong SAR as an anchor for monetary and financial stability, and noted the staff assessment that the real effective exchange rate of the Hong Kong dollar continues to be broadly in line with economic fundamentals. Given the importance of 
maintaining price flexibility to facilitate real exchange rate adjustment to external shocks, Directors urged caution in setting a statutory minimum wage, taking into account the need to protect low-income workers while also minimizing labor market distortion.

Directors welcomed the robustness of the Hong Kong banking system, the result of banks' careful risk management and the authorities' vigilant, prudent regulation and enforcement. Hong Kong SAR, in coordination with Singapore and Malaysia, is well advanced in planning an exit from the blanket deposit guarantee, which has been instrumental in restoring confidence since its introduction in October 2008. Directors supported the proposal to increase the deposit protection limit in line with the coverage in other jurisdictions.

Noting that the recovery is still fragile, Directors endorsed plans to maintain fiscal support in the upcoming 2010/11 budget, including spending on key infrastructure projects and social programs. They encouraged further steps to improve fiscal reporting and strengthen medium-term expenditure planning. Directors commended the authorities for their commitment to health care reform, which aims at reducing the burden on public finances while safeguarding the existing commitment to support those most in need of public health care services. They considered it prudent to phase in supplementary sources of financing at an early stage.

Directors highlighted the urgency of upgrading the quality and expanding the range of services provided by Hong Kong SAR, in view of the shift in the Mainland's growth strategy away from exports to domestic consumption. Potential areas include tourism and leisure, health care, and higher education. Directors also encouraged the authorities to continue to explore ways to develop Hong Kong SAR into an offshore renminbi business center.

Public Information Notices (PINs) form part of the IMF's efforts to promote transparency of the IMF's views and analysis of economic developments and policies. With the consent of the country (or countries) concerned, PINs are issued after Executive Board discussions of Article IV consultations with member countries, of its surveillance of developments at the regional level, of post-program monitoring, and of ex post assessments of member countries with longer-term program engagements. PINs are also issued after Executive Board discussions of general policy matters, unless otherwise decided by the Executive Board in a particular case. The staff report (use the free Adobe Acrobat Reader to view the pdf file) for the 2009 Article IV Consultation with People's Republic of China — Hong Kong Special Administrative Region is also available. 
Hong Kong SAR: Selected Economic and Financial Indicators, 2006-10 ${ }^{1 /}$

Real GDP (percent change)

Contribution

Domestic demand

Private consumption

Government consumption

Gross fixed capital formation

Inventories

Net exports

2007

2008

2009

2010

Inflation (percent change)

Consumer prices

GDP deflator

Employment (percent change)

Unemployment rate (percent, period average)

Real wages

Government budget (percent of GDP)

Revenue

Expenditure

Consolidated budget balance

Fiscal reserves as of March 31

Money and credit (percent change, end-period)

Narrow money (M1)

Broad money (M3)

Loans for use in Hong Kong SAR

Interest rates (percent, end-period)

Best lending rate

Three-month HIBOR

Asset prices

Hang Seng stock index (end of period, 1964=100)

Hang Seng stock index (percent change)

Residential property prices (end of period, percent change)

Merchandise trade (percent change)

Export volume

Import volume

External balances (percent of GDP)

Merchandise trade balance

Domestic exports

Re-exports

Imports

Current account

Foreign exchange reserves $2 /$

In billions of U.S. dollars, end-of-period

In months of retained imports

In percent of broad money (M3)

Exchange rate

Linked rate (fixed)

Market rate (HK\$/US\$1, period average)

Real effective rate (period average, $2000=100$ ) 3 /

Sources: CEIC Database; and staff estimates and projections.

$1 /$ Unless otherwise stated, all growth rates are for year-on-year.

2/ Includes Land Fund assets.

3/ IMF staff estimates.

Staff Proj.

7.0
5.3
3.5
0.0
1.5
0.2
1.7

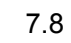

3.8

19,965

34.2

4.1

27,813
39.3

39.3
25.7

9.3

9.2

$-7.4$

9.4

157.8

174.6

12.1

133.2

18.6

20.3

7

6.4

2.4

$$
-2.0
$$

5.0

6.9

5.0

0.2

0.7

0.9

$-0.6$

0.7

$$
0.9
$$

0.1

$-0.1$

$-0.2$

$$
1.6
$$

$-0.7$

$-0.3$

0.6

$-1.0$

0.0

$-1.3$

2.0

2.9

4.3

$$
1.4
$$

$\begin{array}{ll}-1.0 & 0.5\end{array}$

2.2

4.0

0.5

1.5

$$
3.5
$$

$$
0.5
$$

\section{2}

14.5

14.5
7.7

18.9

18.6

0.2

29.5

$\begin{array}{ll}-0.6 & 2.0\end{array}$

$\begin{array}{ll}-0.2 & 1.8\end{array}$

$5.1 \quad 4.8$

$$
30.5
$$

4.7

$$
\begin{aligned}
& 25.4 \\
& 20.6 \\
& 15.2
\end{aligned}
$$

\section{7}

$$
2.6
$$$$
11.0
$$

$$
6.8
$$

5.0$$
0.9
$$

14,387

$-48.3$

$$
-11.1
$$

$\begin{array}{ll}17.8 & 16.0 \\ 18.7 & 17.4 \\ -0.9 & -1.4 \\ 29.2 & 25.8\end{array}$

25.8

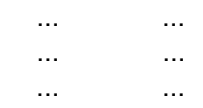

7.0

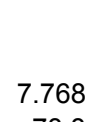

7.0
8.8

1.9

$\begin{array}{ll}-11.4 & 3.2 \\ -10.5 & 2.7\end{array}$

-9.5
7.3
159.8
176.6

176.6

12.3

$-10.7$

$\begin{array}{ll}-11.0 & -9.5 \\ 3.1 & 2.8\end{array}$

6.1

163.5

180.3

3.1

2.8

$149.7 \quad 149.9$

$163.8 \quad 162.2$

$\begin{array}{lll}14.2 & 11.2 & 11.9\end{array}$

78.8

152.7
19.5

182.5

233.

32.6

236.8

22.6

HK\$7.80/US\$1

$\begin{array}{ll}7.801 & 7.787\end{array}$

$74.6 \quad 72.0$

\section{6}

0.6

0.9

0.4

8

\section{.0}

$-1.4$

.

.5

